\title{
Diversity of Leptogium (Collemataceae, Ascomycota) in East African Montane Ecosystems
}

\author{
Ulla Kaasalainen ${ }^{1,2, *(D)}$, Veera Tuovinen ${ }^{3}$, Paul M. Kirika ${ }^{4}$, Neduvoto P. Mollel ${ }^{5}$, Andreas Hemp ${ }^{6}$ iD and \\ Jouko Rikkinen ${ }^{2,7}$ (D)
}

check for updates

Citation: Kaasalainen, U.; Tuovinen, V.; Kirika, P.M.; Mollel, N.P.; Hemp,

A.; Rikkinen, J. Diversity of Leptogium (Collemataceae, Ascomycota) in East African Montane Ecosystems. Microorganisms 2021, 9, 314. https: / / doi.org/10.3390/ microorganisms 9020314

Academic Editors: Alberto

Miguel Stchigel,

Dea Garcia-Hermoso, Yasmina

Marín Félix and Michael J. Bidochka

Received: 16 December 2020

Accepted: 29 January 2021

Published: 3 February 2021

Publisher's Note: MDPI stays neutral with regard to jurisdictional claims in published maps and institutional affiliations.

Copyright: (C) 2021 by the authors. Licensee MDPI, Basel, Switzerland. This article is an open access article distributed under the terms and conditions of the Creative Commons Attribution (CC BY) license (https:// creativecommons.org/licenses/by/ $4.0 /)$.
1 Department of Geobiology, University of Göttingen, Goldschmidtstraße 3, 37077 Göttingen, Germany

2 Finnish Museum of Natural History, P.O. Box 7, University of Helsinki, 00014 Helsinki, Finland; jouko.rikkinen@helsinki.fi

3 Department of Ecology and Genetics, Uppsala University, Norbyvägen 18D, 75236 Uppsala, Sweden; veera.tuovinen@ebc.uu.se

4 National Museums of Kenya, East African Herbarium, Museum Hill Road, P.O. Box 45166, Nairobi 00100, Kenya; pkirika@museums.or.ke

5 National Herbarium, Tropical Pesticides Research Institute, P.O. Box 3024, Arusha 23201, Tanzania; neduvoto.mollel@tpri.go.tz

6 Department of Plant Systematics, University of Bayreuth, Universitätsstr. 30, 95440 Bayreuth, Germany; andreas.hemp@uni-bayreuth.de

7 Organismal and Evolutionary Biology Research Programme, Faculty of Biological and Environmental Sciences, University of Helsinki, P.O. Box 65, 00014 Helsinki, Finland

* Correspondence: ulla.kaasalainen@uni-goettingen.de or ulla.kaasalainen@helsinki.fi

\begin{abstract}
Tropical mountains and especially their forests are hot spots of biodiversity threatened by human population pressure and climate change. The diversity of lichens in tropical Africa is especially poorly known. Here we use the mtSSU and nuITS molecular markers together with morphology and ecology to assess Leptogium (Peltigerales, Ascomycota) diversity in the tropical mountains of Taita Hills and Mt. Kasigau in Kenya and Mt. Kilimanjaro in Tanzania. The sampled habitats cover a wide range of ecosystems from savanna to alpine heath vegetation and from relatively natural forests to agricultural environments and plantation forests. We demonstrate that Leptogium diversity in Africa is much higher than previously known and provide preliminary data on over 70 putative species, including nine established species previously known from the area and over 60 phylogenetically, morphologically, and/or ecologically defined Operational Taxonomic Units (OTUs). Many traditional species concepts are shown to represent morphotypes comprised of several taxa. Many of the species were only found from specific ecosystems and/or restricted habitats and are thus threatened by ongoing habitat fragmentation and degradation of the natural environment. Our results emphasize the importance of molecular markers in species inventories of highly diverse organism groups and geographical areas.
\end{abstract}

Keywords: biodiversity hotspot; Mount Kilimanjaro; Taita Hills; Mount Kasigau

\section{Introduction}

Tropical mountains and especially the montane forests are hot spots of biodiversity and endemism and may represent true evolutionary cradles especially for neoendemics [1-5]. The tropical rainforests of eastern Africa originated approximately 30 million years ago and have persisted through climatic fluctuations, mainly due to the atmospheric moisture supplied by remarkably stable Indian Ocean currents [6]. There, a very complex climatic history has fragmented a once extensive ancient forest ecosystem and given rise to many unique habitats with high levels of local endemism [1,2,5-7]. The windward slopes of many East African mountains benefit from moisture brought by the trade winds and sustain the last remaining fragments of East African montane rain forests, surrounded by more extensive arid forests and woodlands [6]. 
The Taita Hills in south-eastern Kenya form the northernmost section of the ancient Eastern Arc Mountains. The evergreen montane forests on the Eastern Arc are probably the oldest remaining forests in East Africa, and they effectively link the forests of the Indian Ocean coast to the tropical forests of central Africa and the younger volcanic mountains of the Rift Valley [8,9]. Together with the coastal forests of Tanzania and Kenya, the montane forests of the Taita Hills represent a hotspot of global biodiversity with a high number of endemic vertebrates and plants [1,10-12]. On the other hand, the much younger volcanic mountains, including Mt. Kilimanjaro, also support high concentrations of biodiversity due to the steep environmental gradients of their slopes. Even though the level of endemism on Mt. Kilimanjaro is believed to be lower than on that of nearby Eastern Arc Mountains, this may more reflect the results of anthropogenic influence and the destruction of lowermontane forests, rather than the relatively young age of the mountain [13].

Tropical forests and their biodiversity worldwide are threatened by human population pressure and climate change [14,15]. Especially in sub-Saharan Africa, the forest loss proceeds at an alarming rate and is particularly severe in the Afromontane areas [16]. For example, in the Taita Hills the indigenous forest area decreased 50\% just between 1955 and 2004, and the remaining forests have suffered substantial degradation due to agricultural expansion [17]. The forests of East Africa are already among the most threatened regions of global biodiversity and extinction risk for many organisms is still increasing [18,19]. On Mt. Kilimanjaro, forest corridors to nearby mountains have vanished due to deforestation, leaving the mountain isolated [5]. At the higher altitudes, the montane ecosystems are influenced for example by climate change-driven forest fires [20] and altogether, Kilimanjaro has lost about $50 \%$ of its forest cover since the beginning of the last century [13]. In general, habitat destruction is the leading cause of species extinction and this is especially true in the tropics [21,22]. For example, tropical epiphytes are severely threatened by deforestation and disturbance $[23,24]$. It is suspected that numerous plant and animal species, including many of the local endemics, currently experience great difficulties in maintaining stable populations in the highly fragmented forest landscape of the Taita Hills [25-27]. This is probably true also for epiphytic lichens and bryophytes, but so far, no studies have dealt with this issue. Even on a general level, the lichen flora of tropical Africa is still very poorly known.

Leptogium (Ach.) Gray (Collemataceae, Ascomycota) is a genus of approximately a hundred foliose, mainly epiphytic macrolichen species with a nearly cosmopolitan but predominately humid temperate and tropical distribution [28]. The application of molecular phylogenetic methods has led to the revision of Collemataceae and re-evaluation of the taxonomic value of many morphological characters [28-30]. For example, a number of species previously placed in Leptogium were moved into their own genus, Scytinium (Ach.) Gray, while some taxa from other genera have transferred into Leptogium [28,31]. In 1988, Swinscow and Krog [32] listed 24 Leptogium species from East Africa, including collections from Ethiopia, Kenya, Tanzania, and Uganda. Since then, few further species inventories dealing with Leptogium species have been made in the region [33-35]. However, one such study recently demonstrated that East African specimens previously identified as Leptogium hibernicum M. E. Mitch. ex P. M. Jørg. actually represent a separate lineage, L. krogiae Bjelland, Frisch \& Bendiksby, so far only known from East Africa [36]. In addition, Leptogium ethiopicum C.W. Dodge (1964), for a time considered a synonym of L. burgessii, was reinstated as a separate species [37]. In conclusion, 25 Leptogium species are currently listed from East Africa, these including: L. adpressum Nyl., L. asiaticum P.M. Jørg., L. austroamericanum (Malme) C.W. Dodge, L. azureum (Sw.) Mont., L. brebissonii Mont., L. burgessii (L.) Mont., L. burnetiae C.W. Dodge, L. caespitosum (Taylor) Swinscow \& Krog, L. cochleatum (Dicks.) P.M. Jørg. \& P. James, L. coralloideum (Meyen \& Flot.) Vain., L. cyanescens (Ach.) Körb., L. digitatum (A. Massal.) Zahlbr., L. ethiopicum, L. furfuraceum (Harm.) Sierk, L. javanicum Mont., L. juressianum Tav., L. krogiae, L. laceroides de Lesd., L. marginellum (Sw.) Gray, L. phyllocarpum (Pers.) Mont., L. punctulatum Nyl., L. resupinans Nyl., L. rivulare (Ach.) Mont., L. sessile Vain., and L. vesiculosum (Sw.) Malme [32,33,36]. Many of these taxa are 
currently perceived to have wide distributions in the tropics and in temperate regions, and the types of a vast majority have been described from localities outside Africa.

Here, we examine the diversity and habitat ecology of Leptogium on several East African mountains, including the Taita Hills and Mt. Kasigau in Kenya and Mt. Kilimanjaro in Tanzania. The study is mostly based on new specimens collected by the authors in 20092017 from East Africa.

\section{Materials and Methods}

\subsection{Study Area and Sampling}

The Taita Hills and the neighboring Mt. Kasigau in SW Kenya and Mt. Kilimanjaro in NW Tanzania are three isolated mountain blocks all situated less than $400 \mathrm{~km}$ south of the Equator. They are separated by semiarid plains at approximately $600 \mathrm{~m}$ above sea level, where the climate is tropical with two distinct rainy seasons. While the amount of precipitation and temperature vary with altitude, the windward southern slopes of the mountains benefit from moisture brought by the trade winds from the Indian Ocean, supporting evergreen montane "cloud forest". The moist and relatively cool local climate of the montane forest ecosystems provides favorable conditions for the development of diverse lichen and bryophyte communities and abundant epiphyte biomass.

The Taita Hills region includes three closely situated massifs (Dabida, Mbololo, Sagalla) and Mt. Kasigau which is located further away. The mountains rise abruptly from the surrounding plains to a series of ridges, reaching $2208 \mathrm{~m}$ at the highest peak Vuria in Dabida. The annual precipitation usually varies between 600 and $1500 \mathrm{~mm}$, but the rainfall on the lowlands at the base of Mt. Kasigau averages only 300-500 mm. On the other hand, some parts of the upper slopes may receive over $2000 \mathrm{~mm}$ of atmospheric moisture annually as a combination of rain and mist $[9,25,38]$. The potential natural vegetation on the upper slopes of the Dabida massif consists of evergreen moist montane forest classified as Ocotea forest, with Cola-Craibia forest in the drier parts of Ngangao and Mbololo and Erica-Maesa forest near the summit of Vuria $[39,40]$. However, long-lasting and intensive human influence has split the indigenous forest into small, isolated patches and none are in pristine condition: most are heavily disturbed, surrounded, or mixed with exotic plantation trees (e.g., Acacia mearnsii, Cupressus lusitanica, Grewillea robusta, and Pinus and Eucalyptus species) and embedded in an intensively used agricultural landscape [10,17,39]. For example, all mature individuals of the keystone tree species Ocotea usambarensis and Podocarpus latifolius have been extracted for timber and are presently only seen in the lower canopy, while the forests are dominated by tree species more typical for early succession and with little commercial value or practical use (e.g., Tabernaemontana stapfiana and Phoenix reclinata) $[10,25,40,41]$. In general, the smallest fragments of indigenous forest are most affected by disturbance and presently harbor relatively few woody species [25].

The largest remnants of indigenous closed canopy forest on the Dabida massif include: Ngangao $\left(03^{\circ} 21^{\prime} \mathrm{S}, 38^{\circ} 20^{\prime} \mathrm{E}, 1750-1900 \mathrm{~m}\right.$ alt.), a relatively large (120 ha) and partly less disturbed forest with abundant indigenous species including for example Albizia gummifera, Tabernaemontana stapfiana, Newtonia buchananii, Strombosia scheffleri, and Macaranga capensis, and Cola greenwayi and Craibia zimmermannii in the drier parts of the forest [40-42]; Chawia $\left(3^{\circ} 28^{\prime} \mathrm{S}, 38^{\circ} 20^{\prime} \mathrm{E}, 1500-1600 \mathrm{~m}\right.$ alt.), a heavily disturbed forest area of 111 ha including plantations of exotic trees and 86 ha of indigenous forest with for example Tabernaemontana stapfiana, Albizia gummifera, Syzygium sclerophyllum, Strombosia scheffleri, and Phoenix reclinata [17,41,42]; Vuria ( $3^{\circ} 25^{\prime} \mathrm{S}, 38^{\circ} 17^{\prime} \mathrm{E}, 2000-2200 \mathrm{~m}$ alt.), with approximately 100 ha of heavily disturbed forest with less than 1 ha of indigenous forest which however partially represents very dense and humid cloud forest [42,43]; Fururu $\left(3^{\circ} 25^{\prime} \mathrm{S}, 38^{\circ} 20^{\prime} \mathrm{E}, 1650-1750\right.$ $\mathrm{m}$ alt.), Macha $\left(03^{\circ} 25^{\prime} \mathrm{S}, 38^{\circ} 21^{\prime} \mathrm{E}, 1600 \mathrm{~m}\right.$ alt. $)$, Mwachora $\left(03^{\circ} 25^{\prime} \mathrm{S}, 38^{\circ} 22^{\prime} \mathrm{E}, 1650 \mathrm{~m}\right.$ alt. $)$, and Yale $\left(03^{\circ} 24^{\prime} \mathrm{S}, 38^{\circ} 20^{\prime} \mathrm{E}, 1850 \mathrm{~m}\right.$ alt. $)$, the first with 8 ha and the rest approximately 2 ha of indigenous forest each, are all heavily disturbed and intermixed with exotic plantations and agricultural land with indigenous species such as Tabernaemontana stapfiana, Phoenix reclinata, and Maesa lanceolata [41,42]. In addition to these protected forests, there are nu- 
merous minute patches of indigenous forest vegetation, like the one on Shomoto Hill with less than 0.2 ha of forest and just a few individual indigenous trees.

Mt. Kasigau ( $\left.3^{\circ} 30^{\prime} \mathrm{S}, 38^{\circ} 39^{\prime} \mathrm{E}\right)$, some $50 \mathrm{~km}$ SE from the Taita Hills, rises very steeply from the surrounding plains in $600 \mathrm{~m}$ to the summit at $1641 \mathrm{~m}$. Starting as an AcaciaCommiphora bushland of the surrounding plains, the vegetation transitions through lower montane and Euphorbia woodlands and riverine forests (600-1000 m alt.), to semievergreen woodland $(890-1250 \mathrm{~m})$, evergreen forest $(1086-1380 \mathrm{~m})$, and finally to cloud forest (> $1470 \mathrm{~m}$ ) [44,45]. The woody flora of Mt. Kasigau represents a special mix of Somalia-Masai, Afromontane and Coastal floristic affinities [45]. Additionally, the Mt. Kasigau forest has remained relatively undisturbed and also conserved a high coverage of the lowerelevation woodlands [45], offering a relatively unique and invaluable continuous transition of vegetation from the surrounding savanna to montane forest. Thus, the continuous forest and woodland area of Mt. Kasigau is significantly larger than the protected evergreen montane forest (203 ha).

Mt. Kilimanjaro is a relatively young dormant volcano of less than one million years old. The highest peak is almost six kilometers high and $4877 \mathrm{~m}$ higher than the surrounding savanna; the remaining forest zones of the mountain are now mainly protected as a part of the Kilimanjaro National Park. The height provides for a huge range of natural vegetation types; however, the pressure of human population has led to increasing water demands, illegal logging, and grazing pressure [46]. For example, as in Taita Hills, Ocotea usambarensis is extinct from many parts of the natural Ocotea forest, and the upper forest boundary has lowered significantly due to fire $[13,20]$. In the lower elevations, natural savanna, dry woodlands, and lower montane forest have for a large part been converted into agriculture [5,47]. As a result, the slope of Mt. Kilimanjaro supports several prominent natural and human-modified ecosystems, of which the following were sampled for this study: natural savanna and maize fields (800-1100 m); lower montane forests, traditional Chagga home gardens, commercial coffee farms, and grasslands (1100-2000 m); montane Ocotea forest and selectively logged Ocotea forest (2100-2800 m); upper montane Podocarpus forest and Podocarpus forest replaced by Erica excelsa forest as a result of fire (2800-3100 m); subalpine Erica trimera forest and fire disturbed Erica forest (3500-4000 m); and alpine Helichrysum heaths (4000-4600 m). Between the ecosystems, the mean annual temperature varies from $23{ }^{\circ} \mathrm{C}$ at the base of the mountain to $4{ }^{\circ} \mathrm{C}$ at the alpine zone, and night frosts occur above $2700 \mathrm{~m}[48,49]$. The relative humidity and precipitation are highest in the montane forest zones within the stable cloud condensation belt (mean annual precipitation over 2000-2400 mm, partly up to $3000 \mathrm{~mm}$ ) from where the precipitation diminishes both up to the Helichrysum heath $(\sim 1300 \mathrm{~mm})$ and down to the savanna $(\sim 700 \mathrm{~mm})$ [48].

The sampling of lichens in the Taita Hills has taken place during several field trips mainly in 2009-2010, covering most of the described forest fragments on the Dabida massif and the nearby areas; in addition to the forest fragments, also the small garden of the University of Helsinki's Taita Research Station in approximately $1200 \mathrm{~m}$ alt. and nearby roadside trees have been sampled. On Mt. Kasigau, most of the specimens were collected during fieldwork in 2010, when four transects were sampled along the northern, southern, eastern, and western slopes of the mountain. The transects reached from the dry woodland on the base of the mountain to the summit with collection plots in approximately $50 \mathrm{~m}$ intervals; a map of the research setting is presented by Enrooth et al. [50]. The sampling in the Kilimanjaro area was done in 2016-2017 along five replicate transects on the southern and southeastern slopes of the mountain; the 65 sampling plots represented the above mentioned 13 natural and disturbed ecosystems, with five replicate plots of each ecosystem, as presented by Rutten et al. [47].

\subsection{Morphological Inspection and Molecular Methods}

The Leptogium specimens were identified based on morphology and existing literature from the area [32,36]. A small fragment of each lichen specimen was used to extract DNA using the DNeasy Plant Mini Kit (Qiagen AB, Sollentuna, Sweden) or GeneJET Genomic 
DNA Purificatiom Kit (Fermentas, Helsinki, Finland or Fisher Scientific GmBH, Schwerte, Germany) following the manufacturer's instructions. After the extraction, fungal nuclear internal transcribed spacer (nuITS: ITS1-5.8S-ITS2) and mitochondrial small subunit $12 \mathrm{~S}$ (mtSSU) gene sequences were obtained for the phylogenetic analyses. PCR amplification of the fungal ITS gene region was performed with the primers ITS5 and ITS4 [51] using the Dynazyme II DNA polymerase (Finnzymes, Helsinki, Finland) following the protocols in Fedrowitz et al. [52] or by using GoTaq DNA polymerase (Promega GmBH, Walldorf, Germany) as follows: $0.2 \mathrm{mM}$ dNTPs, $0.2 \mu \mathrm{M}$ of each primer, $0.5 \mathrm{mg} / \mathrm{mL} \mathrm{BSA}$, and $0.025 \mathrm{U} / \mu \mathrm{L}$ polymerase in a total volume of $50 \mu \mathrm{l}$; with $2 \mathrm{~min}$ in $95^{\circ} \mathrm{C}$ for initial denaturation, followed by 35 cycles of $45 \mathrm{~s}$ in $95^{\circ} \mathrm{C}, 45 \mathrm{~s}$ in $56^{\circ} \mathrm{C}$, and $1 \mathrm{~min}$ in $72{ }^{\circ} \mathrm{C}$, and with a final elongation of $5 \mathrm{~min}$ in $72^{\circ} \mathrm{C}$. Amplification of the $\mathrm{mtSSU}$ region was performed similarly but using the primers $\mathrm{mtSSU} 1$ and $\mathrm{mtSSU} 3 \mathrm{R}$ [53] and with an annealing temperature of $59^{\circ} \mathrm{C}$. The PCR products were purified using GeneJET PCR purification kit (Fermentas, Helsinki, Finland) or the service was provided by the sequencing company. Sequencing was done using the PCR primers by Macrogen Inc. (Seoul, Korea) and LGC Genomics (Berlin, Germany). After sequencing, the chromatograms of all DNA sequences were checked, edited, and aligned using BioEdit 7.0.9 [54], PhyDE-1 v0.997 [55], and/or CodonCode Aligner (CodonCode Corporation, Centerville, MA, USA). The nuITS and mtSSU sequences obtained from the Leptogium specimens are deposited in the NCBI GenBank database. The specimen information, collection localities, and the GenBank accession numbers are listed in Table S1.

\subsection{Data Analyses}

For the first DNA alignment, all newly obtained unique mtSSU variants and the corresponding $5.8 \mathrm{~S}$ sequence were included; additional sequences were downloaded from the NCBI GenBank database when available. The rare insertions within the mtSSU region as well as the extremely variable ITS1 and ITS2 regions of the nuITS were excluded before the analysis. Degelia, Leciophysma, Staurolemma, Rostania, Scytinium, and Collema were chosen as outgroups, based on existing knowledge about Peltigerales and Collemataceae [29]. The initial alignment was constructed on the MAFFT online service [56] after which it was manually adjusted. The phylogenetic analysis was performed using Bayesian inference and the data partitioned according to the marker region. Substitution models for the analysis were selected using jModelTest2 [57], and GTR + I + G was selected for the mtSSU and $\mathrm{K} 80+\mathrm{G}$ for the 5.8S region. The analysis was run using MrBayes (v. 3.2.7a) [58] on the Cipres Science Gateway [59] as described by Olsson et al. [60]. The convergence of the four parallel runs was checked after $1.5 \times 10^{7}$ generations using Tracer (v. 1.5) [61] and graphed using TreeGraph2 (v. 2.15) [62].

Based on the insufficient separation between groups within Clade $\mathrm{R}$, a further analysis was run including only the taxa in Clade R, using the mtSSU and complete ITS region, except for the outgroup taxa (Collema furfuraceum, Leptogium caespitosum, and L. juressianum) for which only the $\mathrm{mtSSU}$ and $5.8 \mathrm{~S}$ regions were included. Long and rare insertions present in only a few sequences were removed and also otherwise the same principles followed as in the first analysis. Selected substitution models were HKY + I for mtSSU, GTR + G for ITS1, K80 for 5.8S, and HKY + G for the ITS2 regions; the analysis was run for $10^{7}$ generations.

Species and Operational Taxonomic Units (OTUs) were defined based on the results of the phylogenetic analyses and morphological and ecological comparisons. Here, OTU refers to a putative species that has not yet been formally described or its species identity cannot be linked to a specific previously known species. Specimens lacking the mtSSU sequence and hence mainly excluded from the first phylogenetic analysis were placed within the clades and OTUs based on the ITS sequences. 


\section{Results}

\section{1. mtSSU and nuITS Molecular Markers in Leptogium}

According to our findings, among Leptogium species, the nuITS region works well in species identification and offers more resolution than the mtSSU, which, however, is more useful for the phylogenetic analysis, especially in some groups. Both ITS1 and ITS2 of the nuITS are extremely variable, and the combined length of the ITS1-5.8S-ITS2 regions vary from approximately 480 nucleotides to over 1010 among the studied Leptogium species (Figure S1), rendering the regions occasionally unalignable even between closely related taxa. The considerable length and/or variability of the region may also affect the success of PCR and sequencing in some species, and occasionally, mainly for some OTUs in Clades $\mathrm{L}, \mathrm{N}$, and Q (Figure S2), full length nuITS regions were not obtained, rendering the length estimations to probable underestimations. Regardless, a clear shift to longer nuITS regions was observed from Clades B-K to Clades L-R (Figure S1). The latter group of clades also formed a monophyletic group in the phylogenetic analysis of mtSSU and $5.8 \mathrm{~S}$ regions (Figure S2).

\subsection{Leptogium Morphotypes}

The phylogenetic analysis grouped our Leptogium specimens into a number of wellestablished species and into many putative taxa (Figure S2). Our results also revealed that the described morphologies of many species previously named to occur in the region [32] are shared by more than one phylogenetically distinct OTUs identified in the analyses (Figure S2). Thus, such traditionally used names clearly refer to morphotypes, i.e., potentially diverse assemblages of Leptogium taxa that have similar (but not necessarily identical) thallus morphology, and which are not necessarily closely related [63]. We name such assemblages as follows (characteristic morphology in parenthesis): Morphotype adpressum (deeply plicate thallus, usually with sack-like thalline nodules), morphotype austroamericanum (slightly striate thallus surface and mainly laminal isidia), morphotype azureum (thin and smooth thallus lacking symbiotic propagules but often fertile and with inconspicuous apothecial margins; Figure 1a), morphotype brebissonii (olive green to brown thallus and dark laminal isidia), morphotype cochleatum (thick, wrinkled to striate thallus lacking symbiotic propagules, but often fertile and with thick apothecial margins; Figure 1d), morphotype coralloideum (deeply plicate thallus with coralloid isidia), morphotype cyanescens (smooth thallus with isidia and phyllidia on thallus margins and lamina; Figure 1b,c), and morphotype phyllocarpum (deeply plicate thallus, lacking thalline nodules, commonly fertile and with phyllidiate apothecial margins; Figure 1e).

The most common morphotypes in our material are cyanescens and azureum, represented by approximately 21 and 14 OTUs, respectively (Figure S2). In addition, morphotypes adpressum and cochleatum are relatively common, the first represented by seven OTUs in three main clades and the latter by five OTUs in four main clades (Figure S2). The morphological distinctions between morphotypes, detected OTUs, and species were not always clear-cut. For example, some morphological characters traditionally used to distinguish between different Leptogium species, such as thallus striae, or type and position of symbiotic propagules, varied even within single, phylogenetically delimited OTUs. The problem of diffuse and partly shared characteristics was encountered especially between the morphotypes azureum and cyanescens, azureum and cochleatum, austroamericanum and cyanescens, and adpressum and coralloideum. 

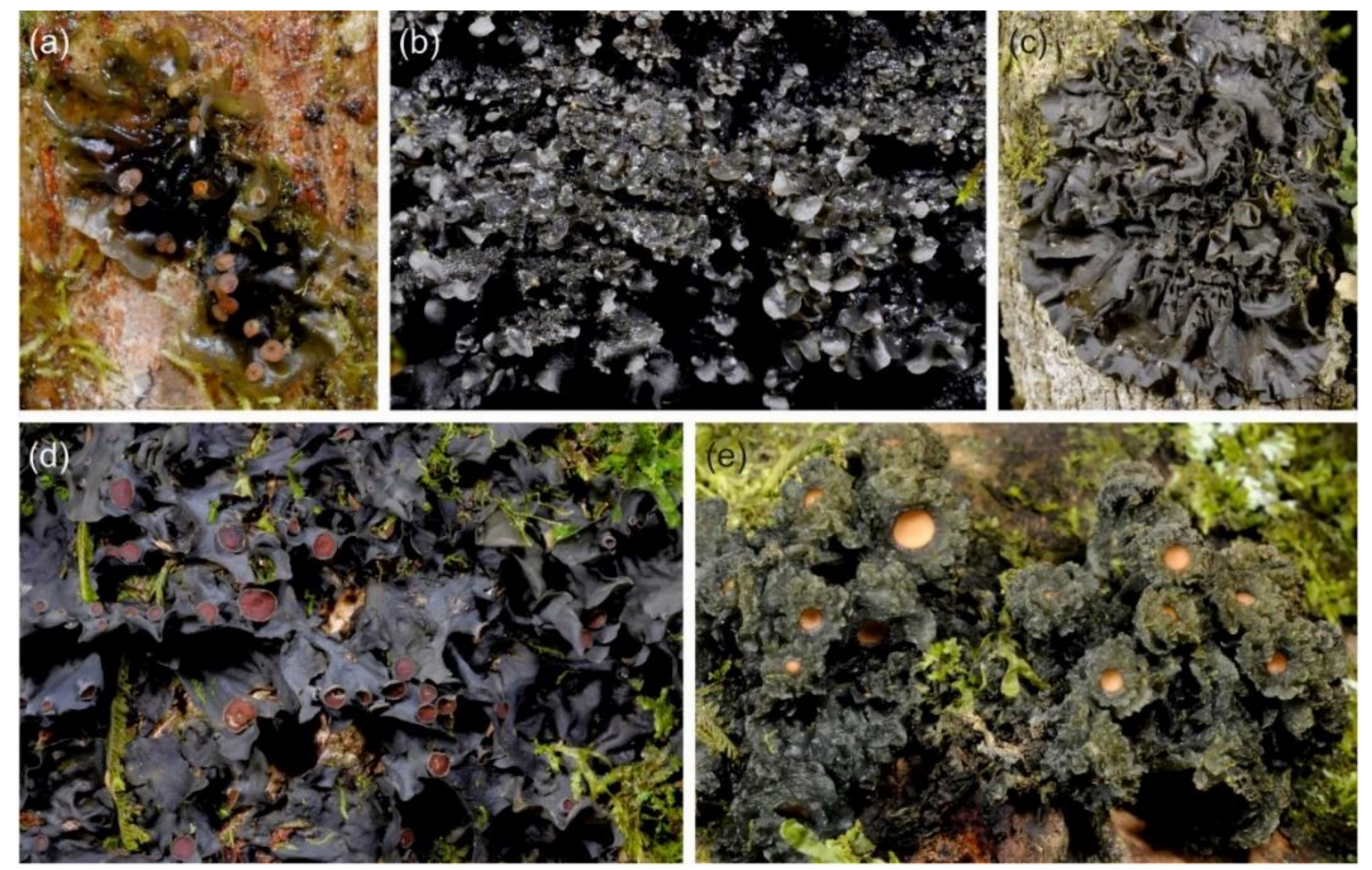

Figure 1. Examples of the Leptogium morphotypes from the montane forests of Kenya. (a) Fertile morphotype azureum. $(\mathbf{b}, \mathbf{c})$ The morphological variation within morphotype cyanescens include isidiate and phyllidiate species, as well as many transitional forms. (d) Morphotype cochleatum with a thick thallus and prominent apothecial margins. (e) Morphotype phyllocarpum with abundantly phyllidiate apothecia.

\subsection{Leptogium Diversity on the Studied East African Mountains}

The phylogenetic analysis of the mtSSU and $5.8 \mathrm{~S}$ regions divide the Leptogium specimens into several distinct clades (Figure S2). Based on the results, the approximately 570 specimens include over 70 established and putative species of Leptogium, identified based on the mtSSU and/or nuITS marker regions and often further distinguished by morphology, distribution, and ecology.

The hairy taxa of the section Mallotium are separated into several clades, one including the more long-haired species (Clade A) and one with shorter hairs (Clade D) (Figures 2 and 3). Some other species of the section Mallotium from other parts of the world are placed between these two major clades. Only one specimen of Clade A, typical L. burnetiae characterized by long white hairs on the lower side and dark isidia on the upper side, was found from Podocarpus forest (2700 m alt.) on Mt. Kilimanjaro. Clade B includes two specimens with adnate, relatively smoot, and nonhairy thalli with abundant symbiotic propagules (phyllidia and/or isidia), both collected from montane forest on Mt. Kasigau (Figure 2). Clade C, here named the Leptogium rivulare group, includes several OTUs, among others, with some resemblance to the species $L$. rivulare but with symbiotic propagules and not exhibiting the characteristic, periodically inundated ecology of L. rivulare (Figure 2). Most of these specimens were collected from relatively dry and open lower-elevation forests of Mt. Kasigau or from homegardens and coffee plantations of Mt. Kilimanjaro. Finally, Clade C also includes two Leptogium specimens collected from Erica forest $(>3500 \mathrm{~m})$ on Mt. Kilimanjaro, one related to Leptogium paramense and the other one to L. crispatellum. 

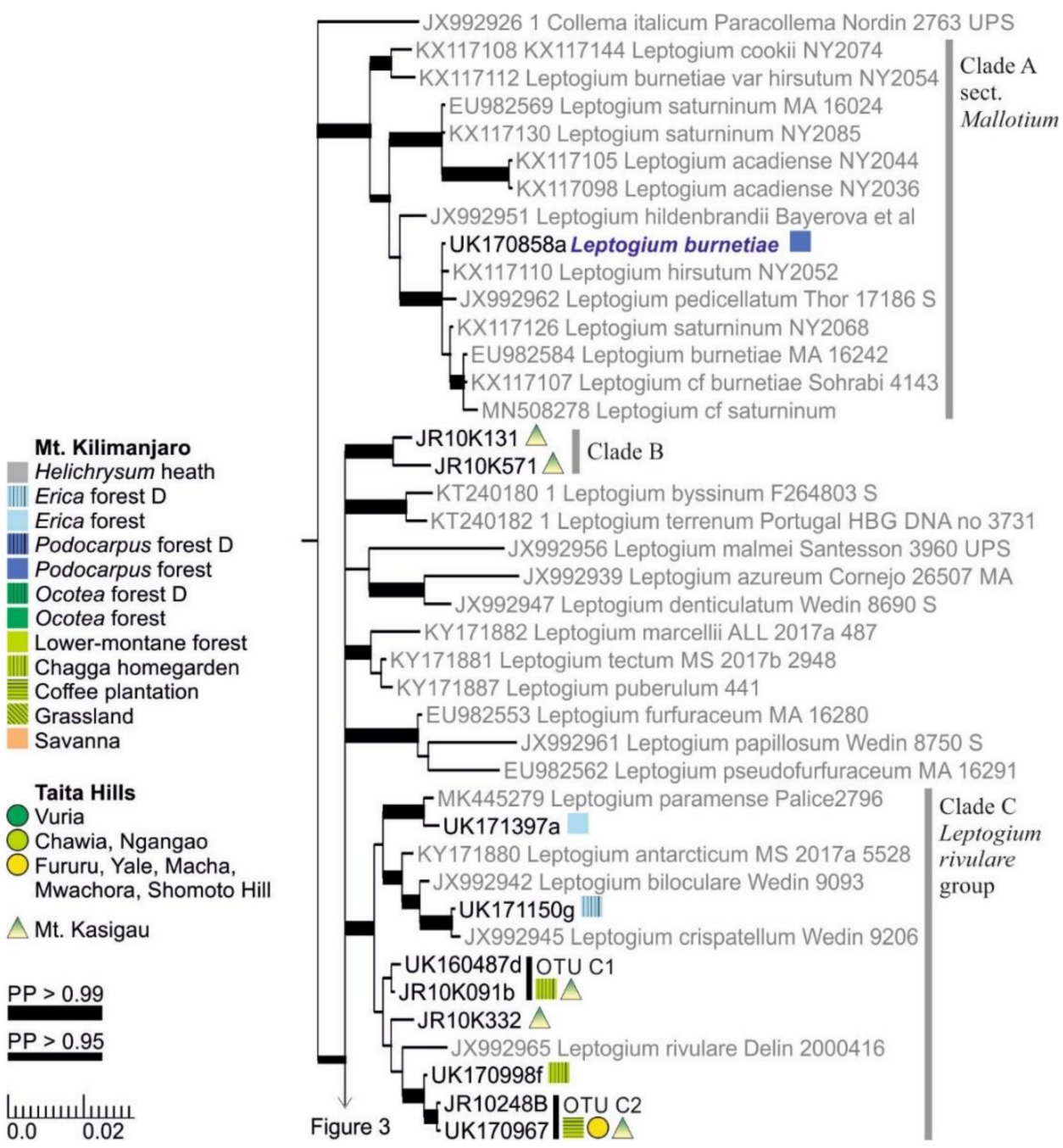

Figure 2. Clades A-C of the Bayesian tree of the genus Leptogium based on the mtSSU and 5.8S marker regions (Figure S2). Newly obtained sequences are in black, including one specimen representing each mtSSU variant; all specimens belonging to each clade are listed in Table S1. Established species are in blue. The colored shapes (rectangle, circle, triangle) show the distribution and abundance of the taxa in the studied regions and ecosystem types: On Mt. Kilimanjaro, each vegetation zone is indicated by color while the disturbed ecosystem types are further separated with grid; the widths of the rectangles indicate the number of sample plots in which the taxon was present in each ecosystem type (square $=1$ ). In Taita Hills, each circle indicates presence in one forest fragment. On Mt. Kasigau, each triangle refers to presence on one collection transect, corresponding to the northern, eastern, southern, and western slopes of the mountain. Strong support ( $>0.95)$ for a clade (posterior probability, PP) is indicated with a thicker branch while the precise values are shown in Figure S2. The scale refers to nucleotide substitutions per site. $\mathrm{D}=$ disturbed. 


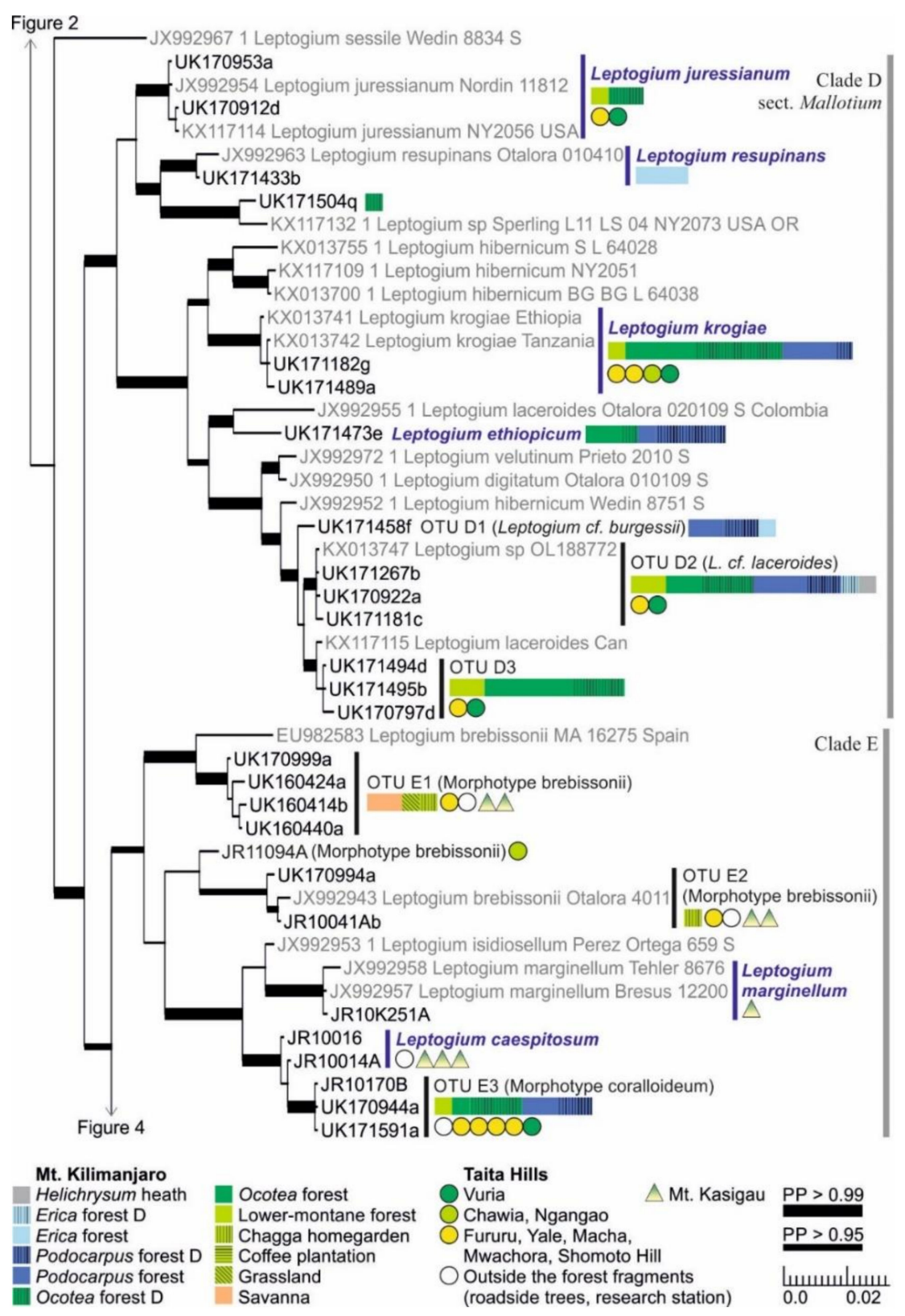

Figure 3. Clades D and E of the Bayesian tree of the genus Leptogium based on the mtSSU and $5.8 \mathrm{~S}$ marker regions (Figure S2). Newly obtained sequences are in black, including one specimen representing each mtSSU variant; all specimens belonging to each clade are listed in Table S1. Established species are in blue. For more detailed explanation, for example, for the colors and shapes indicating the distribution and abundance of taxa, see the caption of Figure 2. D= disturbed; $\mathrm{PP}=$ posterior probability (for the precise values, see Figure S2).

The short-haired taxa of section Mallotium, including several classical species, were further divided into two clades (Clade D; Figure 3). The first group includes Leptogium juressianum, L. resupinans, and specimen UK171504q, with hairs composed of cylindrical cells. L. resupinans, with velvety tomentum covering the upper surface and otherwise smooth thalline exciple, is rare on the study area and was only collected from the highaltitude Erica forest on Mt. Kilimanjaro. L. juressianum, with felt-like hair and marginal isidia, was collected from the lower-montane and Ocotea forests of both Mt. Kilimanjaro and Taita Hills. In addition, one specimen with L. juressianum-like morphology (UK171504q) from the same habitat formed a separate clade with a specimen from the USA. The second 
group within Clade D includes the remaining taxa, all having hairs composed of spherical cells. Leptogium krogiae, which has a striate upper surface and laminal isidia, and usually also coarse tufts of hairs mainly on the lower surface, is a common species in the forests of Mt. Kilimanjaro and Taita Hills. Another common species, Leptogium OTU D2, from the montane forest zones of Mt. Kilimanjaro resembles L. laceroides in having marginal isidia and tufts of hair mainly on the lower side. However, these specimens are placed in a clade separate from specimens of L. laceroides previously sequenced from Colombia and Canada. The second subgroup of Clade D also includes three commonly fertile species with hairs mainly on the lower surface and mainly collected from forests of Mt. Kilimanjaro: Leptogium ethiopicum, with isidiate or nodulous apothecial margins, common in the Ocotea and especially in the Podocarpus forest; Leptogium OTU D1 from the high elevation Podocarpus and Erica forests, resembling L. burgessii with abundantly and clearly phyllidiate apothecial margins; and OTU D3, with specimens with phyllidiate to nodulous apothecial margins.

Clade E (Figure 3) is comprised of Leptogium species with deeply plicate thalli. The specimens from East Africa representing the morphotype brebissonii are divided into three distinct OTUs, and most of the specimens have been collected from lower elevations, from open habitats, including woodlands, savanna, and gardens. Leptogium marginellum, with small marginal and isidiate to phyllidiate apothecia, was collected only once, from the transition zone between semievergreen and evergreen forest on Mt. Kasigau (1100 m alt.). In addition, Leptogium caespitosum, characterized by apothecia with nodulous margins, prefers similar habitats on Mt. Kasigau. Although the specimens of Leptogium caespitosum did not form a monophyletic clade in the analysis of mtSSU and 5.8S regions, the species is supported by several characters within the complete nuITS region. Leptogium OTU E3 of the morphotype coralloideum is the most common species in Clade E in the study area and was found from forests of both Mt. Kilimanjaro and Taita Hills.

Clades F and G both include only one OTU, both belonging to the morphotype cyanescens (Figure 4). Clade $\mathrm{H}$ includes three OTUs, all with deeply plicate and often abundantly nodulous thalli of the morphotype adpressum (Figure 4). Leptogium OTUs H1 and $\mathrm{H} 2$ are not well separated in the phylogenic tree, but their habitats are quite different: $\mathrm{H} 1$ has only been found from relatively low elevations in savanna and garden habitats, while $\mathrm{H} 2$ is relatively common in the Ocotea, Podocarpus, and Erica forests of Mt. Kilimanjaro. The clearly distinct third species of this clade, OTU H3, has been mainly collected from lower-montane forests. The specimens are usually quite nodulous representatives of the morphotype adpressum, but occasionally the nodules turn to more isidium-like structures typical for the morphotype coralloideum.

Leptogium austroamericanum is common in low-elevation woodlands of Mt. Kasigau $(<1200 \mathrm{~m}$ alt.) but has not been found from the other mountains (Figure 4). It groups together with Leptogium austroamericanum from the USA and specimens identified as L. cochleatum and L. cyanescens from Thailand. Specimens of Clade J are combined under one OTU, common in the montane forests of all studied mountains (Figure 4). They all belong to the morphotype cyanescens but include some morphological and phylogenetic variation, but clear links between the subtle morphological variation and phylogenetically supported subgroups has not yet been identified. 


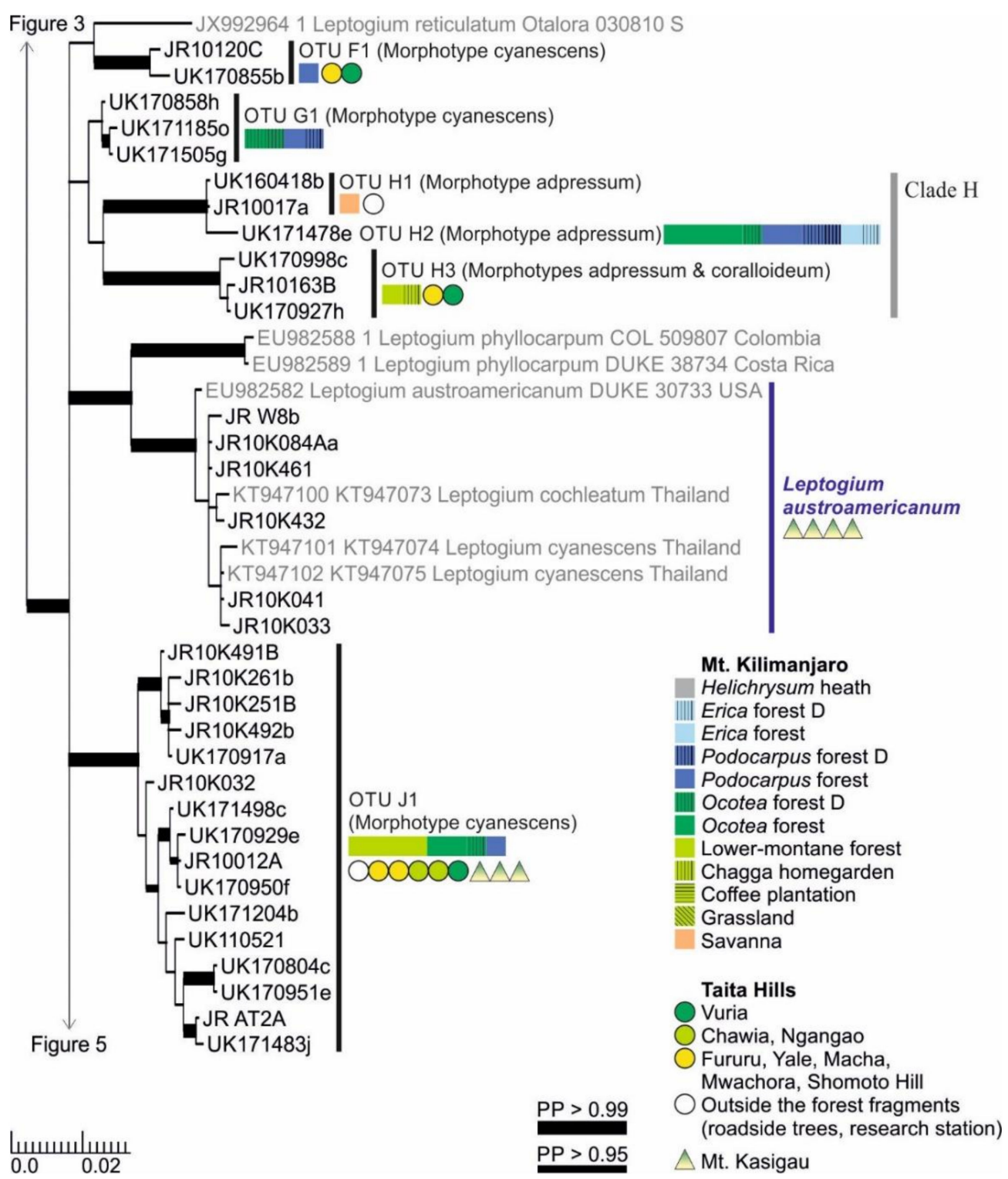

Figure 4. Clades F-J of the Bayesian tree of the genus Leptogium based on the mtSSU and 5.8S marker regions (Figure S2). Newly obtained sequences are in black, including one specimen representing each mtSSU variant; all specimens belonging to each clade are listed in Table S1. Established species are in blue. For more detailed explanation, for example, for the colors and shapes indicating the distribution and abundance of taxa, see the caption of Figure 2. $\mathrm{D}=$ disturbed; $\mathrm{PP}=$ posterior probability (for the precise values, see Figure S2).

Clade K includes a number of Leptogium species from the lower-montane forest zone of the studied mountains (Figure 5). The OTUs mainly belong to the common morphotypes azureum and cyanescens and, occasionally, both morphotypes are present in one OTU. The clade also includes Leptogium javanicum, a species with conspicuous pedicellate apothecia, only collected from a restricted area near the highest summit of the Taita Hills. Another deviant from the general theme is represented by Leptogium OTU K9 with specimens mainly of the morphotype adpressum. Leptogium OTU K9 is common in the low-elevation woodland of Mt. Kasigau but has not been collected from the other mountains. Leptogium OTU K14 with a thick and rugose thallus of the morphotype cochleatum has only been collected from some forest fragments in the Taita Hills. 


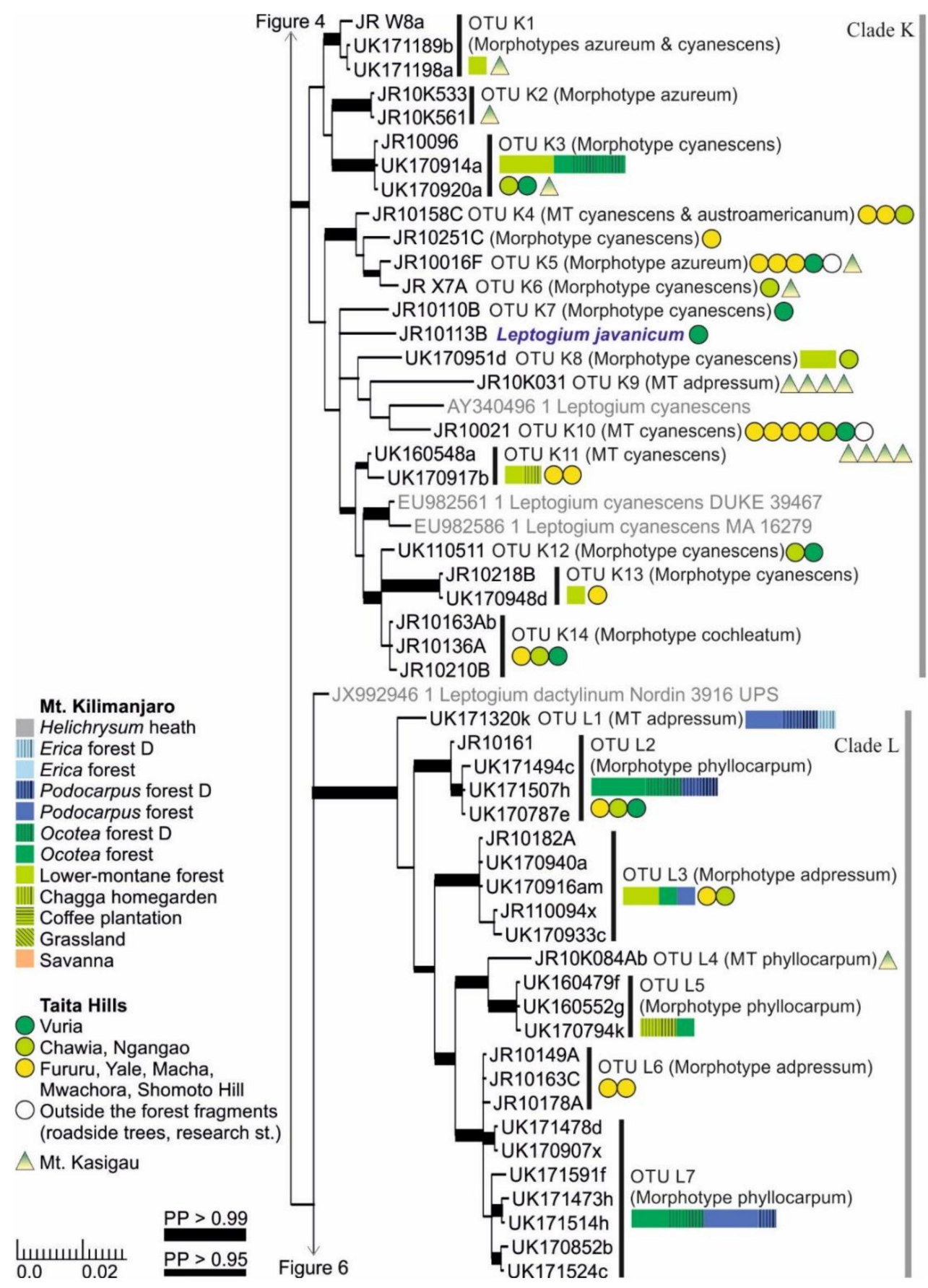

Figure 5. Clades K and L of the Bayesian tree of the genus Leptogium based on the mtSSU and 5.8S marker regions (Figure S2). Newly obtained sequences are in black, including one specimen representing each $\mathrm{mtSSU}$ variant; all specimens belonging to each clade are listed in Table S1. Established species are in blue. For more detailed explanation, for example, for the colors and shapes indicating the distribution and abundance of taxa, see the caption of Figure 2. MT = Morphotype(s); $\mathrm{D}=$ disturbed; $\mathrm{PP}=$ posterior probability (for the precise values, see Figure S2).

Clade L includes seven putative species of the morphotypes adpressum and phyllocarpum (Figure 5). However, previously sequenced Leptogium phyllocarpum sequences in GenBank from Colombia and Costa Rica do not fall into this clade but form a sister group to L. austroamericanum (Figure 4). Leptogium OTUs L6 and L7 are not well separated in the phylogenetic analysis, but their thallus morphology and habitats are quite different, with the former taxon representing the morphotype adpressum and so far only collected from 
the forests of Taita Hills, and the latter being of the morphotype phyllocarpum and so far only known from Ocotea and Podocarpus forests of Mt. Kilimanjaro.

Clades M, N, and P all include only one Leptogium OTU each (Figure 6). Leptogium OTU M1 grows in the lower-elevation woodlands of Mt. Kasigau and represents the morphotype cyanescens. Leptogium OTU N1, which is common in the Ocotea and Podocarpus forests of Mt. Kilimanjaro, has a thick thallus and robust apothecia of the morphotype cochleatum. Leptogium OTU O1, which has only been collected from disturbed environments, has the striate apothecial margins of the morphotype cochleatum, but it has thinner and smoother thallus lobes than OTU N1. Leptogium OTU P1 is common in the lower-montane forests of all three mountains and closely resembles L. austroamericanum, with which it occasionally grows together on Mt. Kasigau.

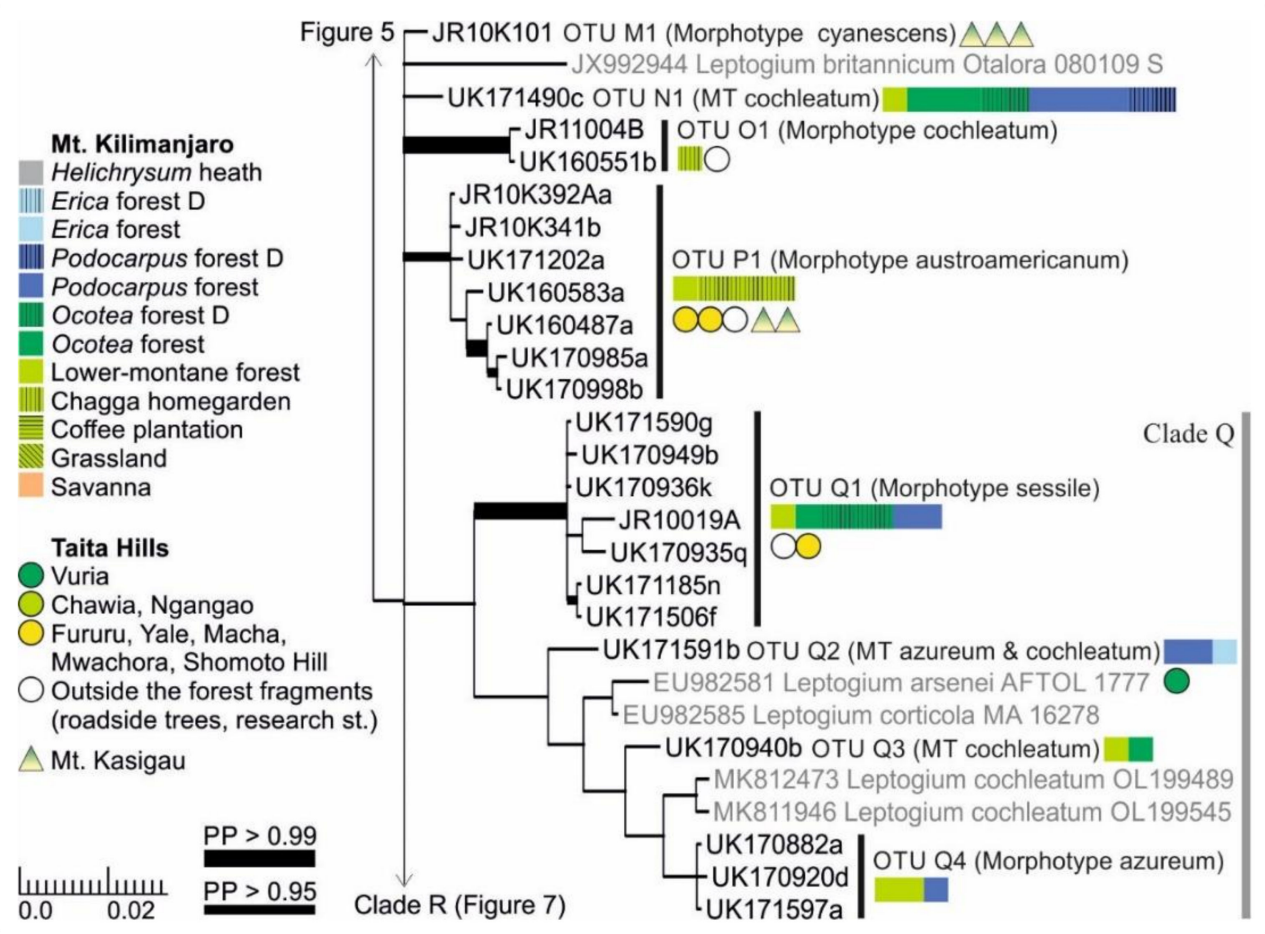

Figure 6. Clades M-Q of the Bayesian tree of the genus Leptogium based on the mtSSU and 5.8S marker regions (Figure S2). Newly obtained sequences are in black, including one specimen representing each mtSSU variant; all specimens belonging to each clade are listed in Table S1. For more detailed explanation, for example, for the colors and shapes indicating the distribution and abundance of taxa, see the caption of Figure 2. MT = Morphotype(s); D = disturbed; PP = posterior probability (for the precise values, see Figure S2).

Clade $\mathrm{Q}$ includes several relatively robust and commonly fertile Leptogium species (Figure 6). Leptogium OTU Q1 mainly resembles L. sessile in having a thick striate to plicate thallus and initially immersed apothecia with thick margins. However, the representative of Leptogium sessile in GenBank from Argentina does not fall within this group but is situated between the L. rivulare group and the short-haired Mallotium group (Clades C and D; Figure S2). Leptogium OTUs Q2-Q4 represent the morphotypes azureum and cochleatum and also group together with two L. cochleatum sequences from Norway. The poor support in this part of the tree is obviously caused by the lack of overlapping marker regions: the GenBank accessions of Leptogium arsenei and L. corticola only include mtSSU sequences and that of L. cochleatum only nuITS sequences.

The separate analysis including the complete mtSSU and nuITS regions for Clade $\mathrm{R}$ (Figure 7) provided some additional clarity and support in comparison to the analysis based on only the mtSSU and $5.8 \mathrm{~S}$ regions (Figure S2). The clade is now split into 14 OTUs that correspond more closely with ecological than morphological differences. All the OTUs represent the morphotypes azureum and cyanescens, or occasionally both. For example, 
within Leptogium OTU R6, even though phylogenetically mixed, all specimens from Mt. Kilimanjaro are fertile and without symbiotic diaspores, while most specimens from Taita Hills have isidia or phyllidia. As a whole, however, the full range of morphological variation within the clade is still insufficiently understood. While most OTUs within this clade appear to prefer lower-montane forests, some, for example OTUs R4, R5, and R9, have only been collected from the high-elevation Podocarpus and Erica forests on Mt. Kilimanjaro.

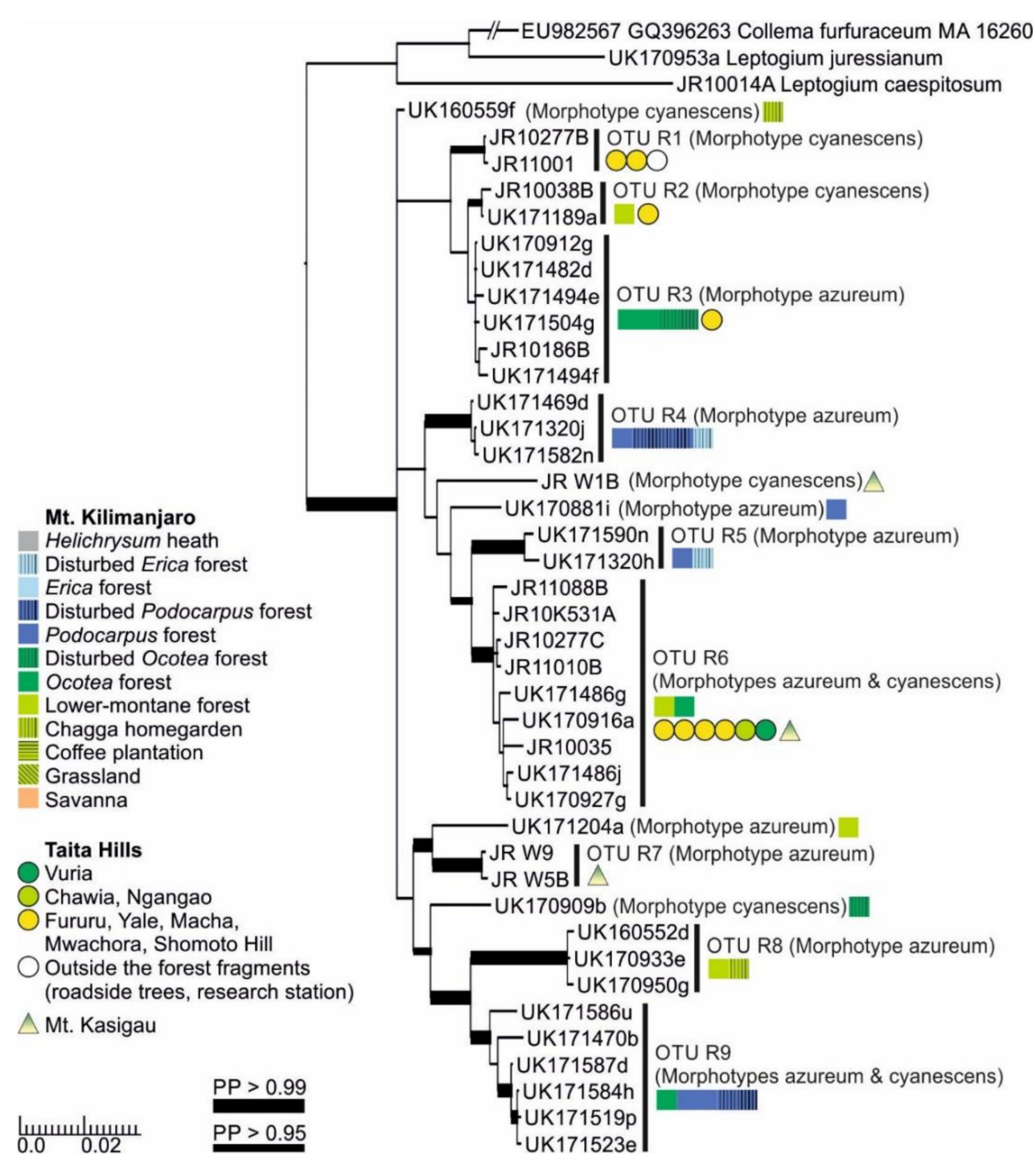

Figure 7. Bayesian tree of the genus Leptogium Clade R (Figure S2) based on the mtSSU and nuITS marker regions. All specimens belonging to each clade are listed in Table S1. For more detailed explanation, for example, for the colors and shapes indicating the distribution and abundance of taxa, see the caption of Figure 2. PP = posterior probability.

\subsection{Diversity and Ecosystems}

Of the three montane regions studied, the highest diversity of putative Leptogium species was found on Mt. Kilimanjaro, with 51 species (Figure 8a). Regarding the different ecosystem types on Mt. Kilimanjaro, lower-montane forest has the highest number of species (22), followed by natural Podocarpus forest (21), disturbed Ocotea forest (18), Ocotea forest (16), and disturbed Podocarpus forest (13). Of the more altered ecosystems, the Chagga homegardens supported 11 different Leptogium species, however, the species number drastically declines with the intensifying disturbance of coffee plantations, grasslands 
and maize fields. In the Taita Hills, we detected 38 species of Leptogium, with the highest diversity (18 species) in the relatively small fragment of montane forest on Vuria; more than ten Leptogium species were also collected from Mwachora, Yale, and, somewhat surprisingly, from a tiny forest remnant on Shomoto Hill. A total of 24 Leptogium species were collected from Mt. Kasigau. The most common Leptogium morphotype in the studied ecosystems was cyanescens and it is particularly common in the low elevation forests and disturbed habitats, especially in the Taita Hills (Figure $8 b$ ). In addition, the proportion of typically fertile species seems to correlate with the elevation, being $58-67 \%$ in the Erica forest, both types of Podocarpus forests and Ocotea forest, $45-47 \%$ in the disturbed Ocotea and lowermontane forest, $35 \%$ at the highest peak of Taita Hills (Vuria), and considerably less in all the other forest fragments in the Taita Hills and the habitat types at lower elevations.

(a)

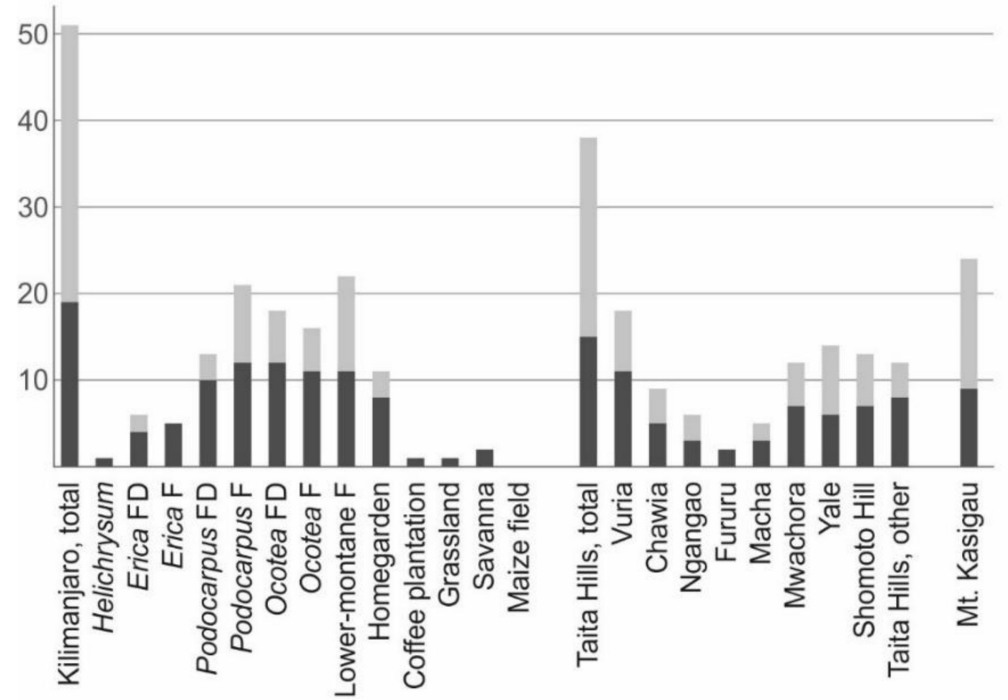

(b) Morphotype adpressum

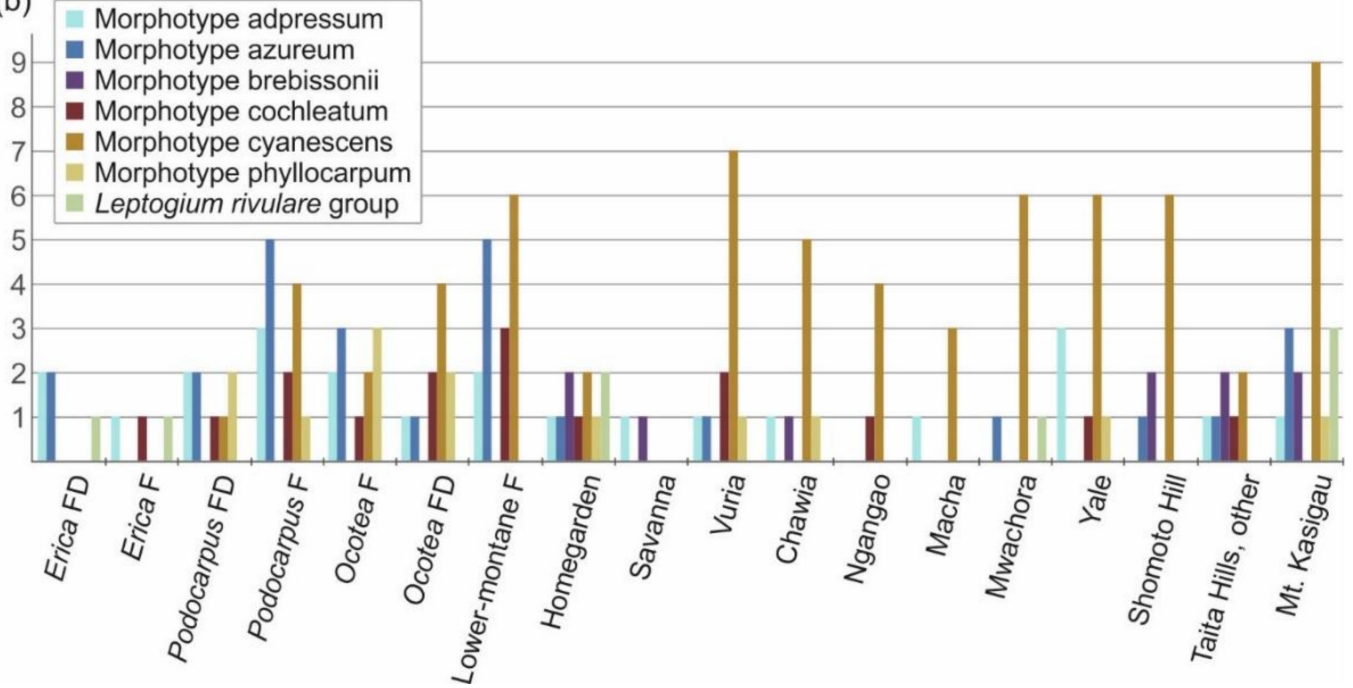

Figure 8. Leptogium diversity in different habitats of East African mountains, represented by different ecosystem types on Mt. Kilimanjaro, different forest fragments in the Taita Hills, and Mt. Kasigau as a whole. (a) Total species diversity of Leptogium in each habitat type (dark grey = proportion of classical, previously known species; light grey = proportion of new diversity discovered in this study). (b) Distribution of the common Leptogium morphotypes among the habitat types (including habitats with at least three different morphotypes). $\mathrm{F}=$ forest; $\mathrm{D}=$ disturbed habitat. 


\section{Discussion}

We discovered over 70 putative Leptogium species from three mountain regions in Kenya and Tanzania, including nine established species previously known from the area and over 60 phylogenetically, morphologically, and/or ecologically defined OTUs, of which some may also represent established species. However, since the traditionally used defining morphological characters are often shared by several putative species and no DNA data from other parts of the world is available for comparison, more definite statements regarding the species identity of these taxa cannot currently be made. A summary of our findings and the Leptogium species and morphotypes in East Africa is provided in Table 1.

Table 1. Diversity of the genus Leptogium in the study area. The distribution in Kenya (K) and Tanzania (T) also includes previous literature reports (Refs); if more than one morphologically similar taxa are present in the region the previous reports are listed after Leptogium morphotypes. Ecology is reported as observed in this study.

\begin{tabular}{|c|c|c|c|c|c|}
\hline Leptogium Species & Distribution & \multicolumn{2}{|c|}{ Ecology } & Comments & Refs \\
\hline L. austroamericanum & K & \multicolumn{2}{|c|}{ Lower-elevation woodland, common. } & & \\
\hline L. burnetiae & $\mathrm{K}, \mathrm{T}$ & \multicolumn{2}{|c|}{ High-montane Podocarpus forest, rare. } & & [32-35] \\
\hline L. caespitosum & $\mathrm{K}, \mathrm{T}$ & \multicolumn{2}{|c|}{$\begin{array}{l}\text { Lower-montane forest/woodland, } \\
\text { common. }\end{array}$} & & [32] \\
\hline L. ethiopicum & $\mathrm{K}, \mathrm{T}^{1}$ & \multicolumn{2}{|c|}{$\begin{array}{c}\text { Montane Podocarpus and Ocotea forest, } \\
\text { common. }\end{array}$} & & {$[64]$} \\
\hline L. javanicum & $\mathrm{K}, \mathrm{T}$ & \multirow{2}{*}{\multicolumn{2}{|c|}{$\begin{array}{l}\text { Montane forest, rare. } \\
\text { Lower-montane and montane forest. }\end{array}$}} & & {$[32,33]$} \\
\hline L. juressianum & $\mathrm{K}, \mathrm{T}^{1}$ & & & & \\
\hline L. krogiae ${ }^{2}$ & $\mathrm{~K}, \mathrm{~T}$ & \multicolumn{2}{|c|}{ Montane forest, common. } & & {$[32,33,36]$} \\
\hline L. marginellum & $\mathrm{K}, \mathrm{T}$ & \multirow{2}{*}{\multicolumn{2}{|c|}{$\begin{array}{l}\text { Lower-montane forest/woodland, rare. } \\
\text { High-montane Erica forest. }\end{array}$}} & & {$[32,33]$} \\
\hline L. resupinans & $\mathrm{K}, \mathrm{T}^{1}$ & & & & {$[32,34]$} \\
\hline \multicolumn{2}{|c|}{ Leptogium morphotypes } & $\begin{array}{l}\text { Putative } \\
\text { species }\end{array}$ & Clade(s) & & \\
\hline Adpressum & $\mathrm{K}, \mathrm{T}$ & 6 & $\mathrm{H}, \mathrm{K}, \mathrm{L}$ & \multirow{4}{*}{$\begin{array}{c}\text { Name species occurs in East } \\
\text { Africa. }\end{array}$} & {$[32,34]$} \\
\hline Austroamericanum & $\mathrm{K}, \mathrm{T}$ & $\sim 2$ & $\mathrm{I},(\mathrm{K}), \mathrm{P}$ & & {$[32,33,35]$} \\
\hline Azureum & $\mathrm{K}, \mathrm{T}$ & $\sim 14$ & $\mathrm{~K}, \mathrm{Q}, \mathrm{R}$ & & {$[32,33,35]$} \\
\hline Brebissonii & $\mathrm{K}, \mathrm{T}^{1}$ & 3 & E & & [32] \\
\hline Burgessii & $\mathrm{K}, \mathrm{T}$ & $1-2$ & $\mathrm{D}$ & $\begin{array}{l}\text { Name species probably } \\
\text { occurs in East Africa. }\end{array}$ & {$[32,35]$} \\
\hline Cochleatum & $\mathrm{K}, \mathrm{T}$ & $4-5$ & $\mathrm{~K}, \mathrm{~N}, \mathrm{O}, \mathrm{Q}$ & \multirow[t]{3}{*}{$\begin{array}{l}\text { Name species probably does } \\
\text { not occur in East Africa. }\end{array}$} & {$[32,33,35]$} \\
\hline Coralloideum & $\mathrm{K}, \mathrm{T}$ & $\sim 1$ & $\mathrm{E},(\mathrm{H})$ & & [32-34] \\
\hline Cyanescens & $\mathrm{K}, \mathrm{T}$ & $\sim 21$ & $\mathrm{~F}, \mathrm{G}, \mathrm{J}, \mathrm{K}, \mathrm{M}, \mathrm{R}$ & & {$[32,33,35]$} \\
\hline Juressianum & $\mathrm{K}, \mathrm{T}$ & 2 & $\mathrm{D}$ & $\begin{array}{c}\text { Name species occurs in East } \\
\text { Africa. }\end{array}$ & [32] \\
\hline Laceroides & $\mathrm{K}, \mathrm{T}$ & 1 & $\mathrm{D}$ & $\begin{array}{l}\text { Name species probably does } \\
\text { not occur in East Africa. }\end{array}$ & [32-34] \\
\hline Phyllocarpum & $\mathrm{K}, \mathrm{T}$ & 4 & $\mathrm{~L}$ & $\begin{array}{l}\text { Name species probably does } \\
\text { not occur in East Africa. }\end{array}$ & {$[32,33]$} \\
\hline Sessile & $\mathrm{K}, \mathrm{T}$ & $\sim 1$ & Q & $\begin{array}{l}\text { Name species probably does } \\
\text { not occur in East Africa. }\end{array}$ & {$[32,33]$} \\
\hline \multicolumn{6}{|c|}{ Other groups } \\
\hline Clade B & $\mathrm{K}$ & $1-2$ & $\mathrm{~B}$ & & \\
\hline L. rivulare group & $\mathrm{K}^{1}, \mathrm{~T}$ & 6 & $\mathrm{C}$ & & [33] \\
\hline \multicolumn{6}{|c|}{ Leptogium species previously reported from East Africa but not found in this study } \\
\hline L. asiaticum & $\mathrm{K}, \mathrm{T}$ & & & & [32] \\
\hline L. digitatum & K & & & & [32] \\
\hline L. furfuraceum & $\mathrm{K}$ & & & & {$[32,35]$} \\
\hline L. punctulatum & - & & & & [32] \\
\hline L. rivulare & $\mathrm{T}$ & & & & [33] \\
\hline L. vesiculosum & $\mathrm{K}, \mathrm{T}$ & & & & [32] \\
\hline
\end{tabular}

${ }^{1}$ New observation for the country. ${ }^{2}$ Reported as Leptogium hibernicum in [32,33]. 
Most of the observed taxa were clearly identified in the phylogenetic analysis of the mtSSU and 5.8S marker regions and supported by morphology and ecology and further comparisons of the complete nuITS region. Of the 25 taxa previously reported from East Africa $[32,33,36]$, we found nine that could be relatively unambiguously identified: Leptogium austroamericanum (Figure 9a), L. burnetiae, L. caespitosum (Figure 9b), L. ethiopicum (Figure 9c), L. javanicum (Figure 9d), L. juressianum, L. krogiae, L. marginellum (Figure 9e,f), and L. resupinans. To our knowledge, Leptogium ethiopicum, L. juressianum, and L. resupinans are new reports for Tanzania, and L. caespitosum, L. ethiopicum, and L. javanicum have not previously been represented by voucher sequences in public databases. Additionally, Leptogium burgessii is very likely present in our material and represented by either OTU D1 or D3, and it is possible that some of the OTUs of the morphotypes adpressum, azureum, brebissonii, and coralloideum also include the name species.
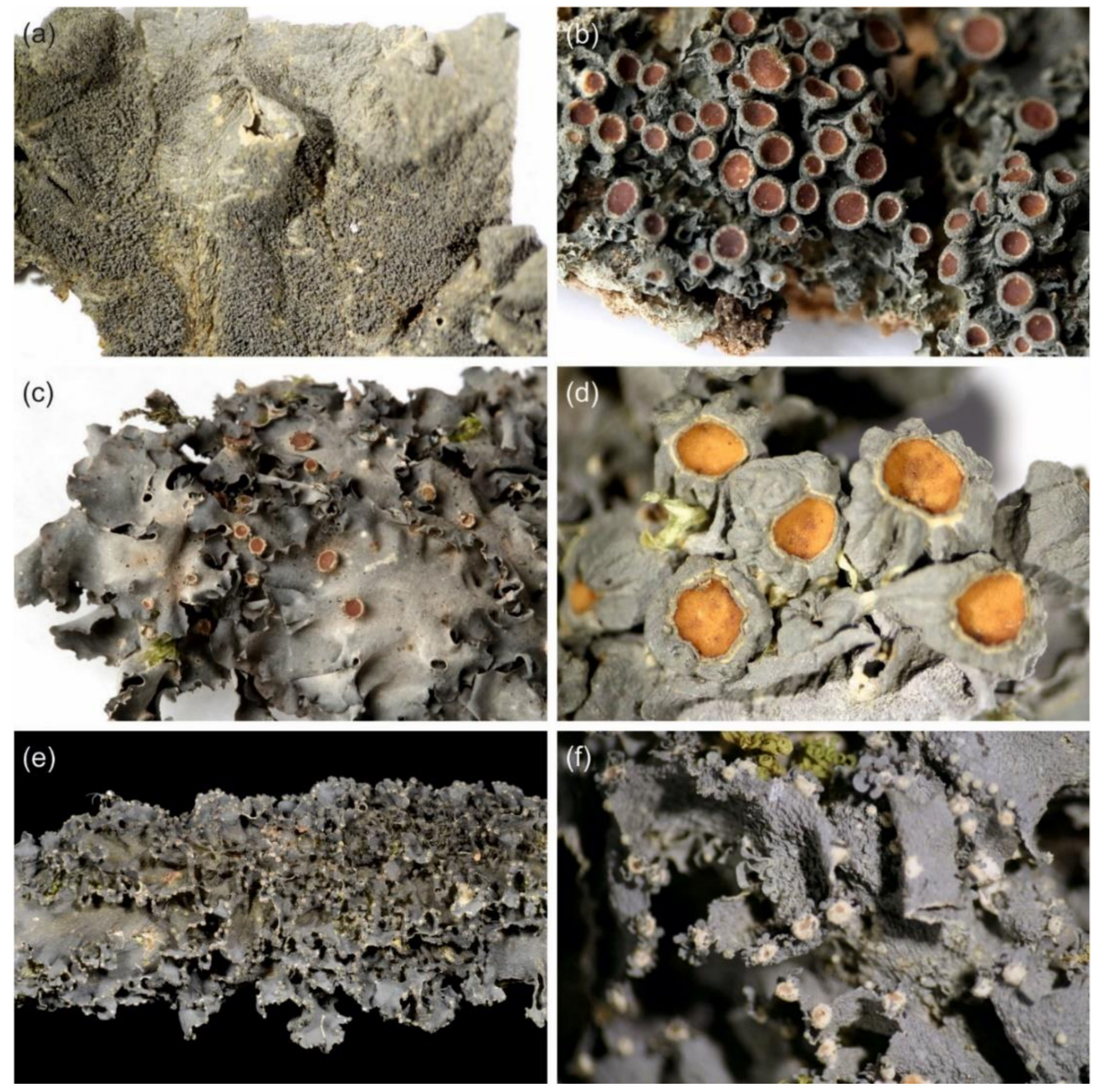

Figure 9. Leptogium species from East Africa. (a) Abundantly isidiate and striate to slightly wrinkled thallus of Leptogium austroamericanum (JR10K461). (b) Abundantly fertile Leptogium caespitosum with nodular apothecial margins (JR10K401A). (c) Leptogium ethiopicum with isidiate apothecial margins (UK171584f). (d) Pedicellate apothecia of Leptogium javanicum (JR10119B). (e) Leptogium marginellum imaged in situ on a branch. (f) The small, phyllidiate, marginal apothecia and wrinkled surface of Leptogium marginellum (JR10K251A).

The identification of Leptogium austroamericanum, L. juressianum, L. krogiae, L. marginellum, and L. resupinans is supported by the phylogenetic analysis and specimens from other parts of the world included in the analysis. The East African specimens of Leptogium austroamericanum, species originally described from Central America [64], fits the 
morphological description of the species and is placed within the same clade with L. austroamericanum from the USA (Figure 4). The clade also includes specimens identified as Leptogium cochleatum and L. cyanescens from Thailand, mixed with the L. austroamericanum specimens from East Africa. However, since there are no significant morphological, ecological, or distributional differences between different East African specimens, or phylogenetic support for further divisions within the clade, all the specimens are, for now, placed under Leptogium austroamericanum. Morphologically, this species may be confused especially with Leptogium OTU P1, which shares some of the habitats with L. austroamericanum but has a wider distribution in the lower-montane forests on all the studied mountains. In addition, Swinscow and Krog [32] acknowledged the presence of a possible second species very similar to Leptogium austroamericanum but differing in some apothecial characters.

Leptogium juressianum, originally described from Portugal [65], occurs on Mt. Kilimanjaro and Taita Hills in the lower-montane and Ocotea forests (1700-2400 m alt.), which is somewhat lower than previously reported [32]. The species can be confused with another species, sharing the same habitat and a similar morphology, represented in our material by only a single specimen (Figure 3). According to Kitaura and Marcelli [66], Leptogium juressianum may represent a species complex and needs to be re-evaluated-our results seem to confirm this.

Leptogium krogiae was recently described from Tanzania [36], and we can confirm that this species is common in the montane forests of East Africa. Leptogium marginellum was originally described from the Caribbean [67] and is also known from Cuba and Ecuador [29]. The species has been previously reported from mountain rainforest and open woodland in Kenya, Tanzania, and Uganda [32,33], but we found only one specimen from a montane forest on Mt. Kasigau.

Leptogium resupinans, originally described from Bolivia [68], is also known from the Canary Islands [29]. We only found the species from undisturbed Erica forests on Mt. Kilimanjaro, which resembles the habitat of the type specimen [32].

Leptogium burnetiae, represented in our material by a single specimen collected from a Podocarpus forest on Mt. Kilimanjaro $(2700 \mathrm{~m})$, well fits the description of the species, originally found from East Africa [69] and the phylogenetic analysis grouped it with other Leptogium burnetiae specimens from different parts of the world (Figure 2).

Leptogium caespitosum was originally described from South Africa [70] and is easy to identify on the basis of its characteristic morphology, especially when fertile. It has previously been reported to be widespread but not common in East Africa [32]. We mainly collected this species from Mt. Kasigau, but it is quite likely to also occur in comparable lower-elevation woodland habitats on the other mountains.

Leptogium ethiopicum, originally described from a high-elevation (> $3000 \mathrm{~m}$ ) Ethiopian montane forest has been previously reported from Kenya [69], and now we found it from high-elevation montane forests on Mt. Kilimanjaro. The species could be confused with Leptogium OTU D3 which, however, seems to prefer lower elevations, including some forest fragments in Taita Hills.

Leptogium javanicum, a species originally described from Java [71], was only found from a fragment of montane mist forest near the summit of Vuria, where the species appears to be locally common. Previously it has been reported from a hand full of locations in Kenya and Tanzania [32,33]. The species has also been reported from Brazil [72], but a comparison with the published description suggests that the Brazilian taxon is not conspecific with our material from Kenya. This supports the interpretation [72] that Leptogium javanicum probably represents a species complex.

In addition to the taxa discussed above, we confirmed the existence of a plethora of other, currently undescribed putative Leptogium species, some of which morphologically greatly resemble previously described taxa. This points towards widespread morphological homoplasy in the genus Leptogium, i.e., the presence of similar morphologies among phylogenetically unrelated taxa. This emphasizes the general need for using DNA markers 
when assessing the diversity of Leptogium species, especially in regions where the diversity has been poorly studied.

Prime examples of morphological homoplasy include the morphotypes adpressum and coralloideum, both including OTUs identified in this study. Both Leptogium adpressum and L. coralloideum have been previously reported from East Africa [32,33] but not originally described from the region [73] and no reference DNA data is available for either species in GenBank. In our material, Leptogium species that share the similar morphology, i.e., grey, deeply plicate thallus either with thalline nodules or isidia, are present in several different clades. Furthermore, the difference between the specimens representing the two morphotypes may sometimes be far from clear-cut. The morphotypes represent at least eight putative species, the morphotype adpressum being clearly more species rich and morphologically diverse (Figure S2). Recent descriptions of Leptogium coralloideum from Brazil [72,74], the type location, suggest that Leptogium OTU E3 might not be Leptogium coralloideum, but one of the other taxa mentioned above might be. Previous reports form East Africa have mentioned Leptogium coralloideum to be common from sea level to high elevations (>3000 m) and L. adpressum to occur at elevations between 1000 and $3400 \mathrm{~m}[32,33]$. Clearly, both statements are oversimplifications of a complex matter.

In addition, Leptogium burgessii is a morphological taxon that had not been previously sequenced and includes more than one possible phylogenetic species in our study area. The two species in our material include Leptogium OTU D1 from the high-montane Podocarpus and Erica forests on Mt. Kilimanjaro and OTU D3 from lower-montane and Ocotea forests of Mt. Kilimanjaro and from the Taita Hills (Figure 3). Previously, Leptogium burgessii has been reported from shady montane forests and the ericaceous zone (1900-3500 m) in East Africa [32,35]. These reports have probably been based on the occurrences of both species we now detected, and possibly also L. ethiopicum, which has been treated as a synonym of L. burgessii [37].

Leptogium brebissonii, originally described from the Canary Islands [75], is comprised of at least four closely related but distinct species, of which three are present in East Africa (Figure 3). The nonmonophyly of L. brebissonii has also been pointed out in a previous study [29]. Based on sequences from the GenBank, one of the East African species also occurs in Colombia, while the species from Spain was not detected in our region. Previously, Leptogium brebissonii has been reported to occur in shady montane forests $(1100-2500 \mathrm{~m}$ ) in Ethiopia, Kenya, and Uganda [32]. Our observations are from slightly lower elevations in savanna, low-elevation woodlands, and lower-montane forest habitats and also include several sampling locations in Tanzania.

Leptogium laceroides, L. sessile, L. cochleatum, and L. phyllocarpum are all species that have been previously reported from East Africa [32-35], but the specimens collected by us do not correspond with published sequences of these species from other parts of the world. The East African specimens resembling Leptogium laceroides and L. sessile, both described from Central America [76,77], represent lineages of their own, but were not grouped together with specimens from Colombia and Argentina (Figures 2 and 5). This suggests that the East African specimens actually represent separate species. Previously, Leptogium laceroides has been reported in East Africa from lower to high elevation montane forests (1500-3400 m) and L. sessile from lower to middle montane habitats (1100-2500 m) [32,33]. In our material, the L. laceroides-like OTU D2 was very common on Mt. Kilimanjaro from the lower-montane forest to very high elevations and was the only Leptogium species found growing in the alpine Helichrysum heath. The L. sessile-like OTU Q1 had a more restricted distribution.

In addition, specimens corresponding morphologically with Leptogium phyllocarpum, originally described from Brazil [78], and Leptogium cochleatum, originally described from England [79], were split into several distinct taxa in the phylogenetic analysis. The specimens of morphotype phyllocarpum were divided into four different species, all within Clade L, and having distributions from lower-montane forests to upper-montane Podocarpus forests. In previous literature, L. phyllocarpum has been reported to be common in 
gardens, woodlands, and forests of East African mountains [32,33]. Specimens of morphotype cochleatum were present in several different clades, including Clade $Q$, which also included Leptogium cochleatum specimens previously sequenced from Norway (Figure 6). We mainly delimited the morphotype cochleatum to specimens with conspicuously thick and rugose thalli and thick apothecial margins, corresponding to the species as portrayed by Swinscow and Krog [32]. Some such specimens came quite close to the L. sessile-like thalli of Leptogium OTU Q1. In the other end of the morphological continuum there were specimens with striate but relatively thin thalli, somewhat closer to the Leptogium cochleatum described from Europe [79]. Previous literature reports Leptogium cochleatum as being fairly common in the montane forests of East Africa [32,35]. We can confirm that especially Leptogium OTU N1 and some other species of this complex are common in some forest zones while others are uncommon, like Leptogium OTU O1, which was only collected from relatively open habitats.

The extreme cases of the morphological homoplasy include the morphotypes azureum and cyanescens. Both thallus morphologies were very common in our East African material and were represented by some OTUs of almost all nonhairy clades (Figure S2). The separation of these morphotypes from others was not always easy and, on several occasions, specimens representing several morphotypes were present within one OTU, especially within Clade R (Figure 7). The main differences between a L. cyanescens-like and a L. azureum-like morphology has classically been that L. cyanescens bears isidia and/or phyllidia, while L. azureum should have neither but tends to be commonly fertile. Our results clearly show that this morphological dichotomy is not always indicative of phylogenetic separation in Leptogium. In general, the morphotype cyanescens is more common in lower-montane forests and especially in the Taita Hills, where it is by far the most common and abundant Leptogium morphotype, while the morphotype azureum is more prevalent at higher elevations and on Mt. Kilimanjaro. Leptogium OTU R6 is an especially interesting case, as the specimens of this OTU collected from the Taita Hills produce symbiotic propagules, while specimens of the same species from Kilimanjaro do not but are commonly fertile!

We did not collect Leptogium asiaticum, L. digitatum, L. furfuraceum, L. punctulatum, L. rivulare, L. vesiculosum, or morphologically similar taxa from our study area, even though all these have been previously reported from East Africa [32,33,35]. Our specimens included several specimens of the Leptogium rivulare group (Figure 2) which, however, did not group together with $L$. rivulare in the phylogenetic analysis, lack apothecia but often have isidia, and have a different ecology than $L$. rivulare. Some of the specimens also bear structures resembling the (semi)marginal globose pycnidia described from L. rivulare in Tanzania [33]. Leptogium asiaticum, L. digitatum, and L. furfuraceum are all hairy Leptogium species reported to be uncommon or rare in the montane forests of Kenya and/or Tanzania [32]. L. punctulatum, characterized by two-layered and folded thallus lobes and attachment pits, has been reported from a single location in Uganda and L. vesiculosum, with conspicuous pedicellate apothecia, is also only known from two locations in East Africa [32].

Of the over 70 Leptogium species and OTUs identified, 23 were only collected from either Mt. Kasigau, a single forest fragment in Taita Hills, or one ecosystem type on Mt. Kilimanjaro. Some of these taxa were collected only once, but the group also included a number of locally common species. This type of distribution was especially characteristic of Mt. Kasigau, which had eight Leptogium species that have so far not been collected from other sites. These include, for example, the locally common Leptogium austroamericanum and OTU K9. Another interesting example is Leptogium OTU K10, which was by far the most common Leptogium species in the woodlands and lower-montane forests on Taita Hills and Mt. Kasigau but seemed to be absent from Mt. Kilimanjaro. One possible reason for this absence could be the lack of suitable habitats: extensive degradation of low elevation forests and woodlands and conversion to agricultural land $[5,17]$ may have largely destroyed its primary habitats. 
As a whole, most observed differences in Leptogium species composition between the different mountains can be explained by differences in the ecosystem types present. Mt. Kilimanjaro has the most extensive environmental gradient ranging from savanna to alpine heath and also the consequent highest number of observed species. The relatively high number of species of Taita Hills in comparison to Mt. Kasigau is probably mainly due to the more excessive, albeit now badly fragmented and partly deteriorated, total area of lower-montane forest in the Taita Hills. The higher proportion of mainly fertile species at the higher elevations, or the higher proportion of symbiotically dispersing species at lower elevations is an interesting finding, which requires further study. Could speciation have been faster in Leptogium species that reproduce mainly via asexual symbiotic diaspores? Could such a phenomenon have been especially pronounced in lower-montane forests with a wide range of available niches? Some lichenized fungi may also expand their ecological tolerance by partnering with variable photobionts [80], and, for species specialized in ecosystems farther from the environmental optimum, distribution via fungal spores may enable them to more often partner with photobionts specialized to the exact conditions of the new habitat.

Our results reveal that the diversity of Leptogium in East Africa is much higher than previously thought, and that the number of species there may exceed what has so far been reported for any other region of the world. The montane forests of East Africa are widely known for their unique biodiversity, and our findings demonstrate that this reputation also holds true for the genus Leptogium. Local endemism may be high, but the poor sampling of other mountain regions and tropics in general, currently prevents definite conclusions. Many of the classical species previously reported from our study area clearly represent morphotypes, i.e., groups of morphologically similar species that are not necessarily closely related or more closely related species complexes. A similar situation has also been observed in many other lichen groups in studies utilizing DNA markers and phylogenetic analysis [81-83], highlighting that some thallus features commonly used in species identification do not always reflect phylogeny and that we still have a poor understanding of factors that affect the development of a lichen phenotype [84-86]. Our results also highlight the perhaps insurmountable challenge of rigorously dealing with intraspecific variability, interspecific overlap, and very limited number of morphological and anatomical characters available for the accurate identification of Leptogium species. They also underline the urgent need for detailed molecular studies of fresh material collected from the type localities of many traditionally delimited Leptogium species, which have so far been thought to have almost cosmopolitan distributions.

\section{Conclusions}

Species diversity in the genus Leptogium is much higher than previously known, especially in East Africa, but probably also in other parts of the world. Many species as traditionally circumscribed represent species groups and the morphological characters used to distinguish between taxa require critical review. At present, reliable estimation of global species diversity and distribution patterns is prevented by insufficient taxon sampling and the lack of molecular data especially from tropical mountain areas, which can be expected to harbor most of the diversity in the genus.

Supplementary Materials: The following are available online at https:/ / www.mdpi.com/2076-2 607/9/2/314/s1, Figure S1: Length variation of the nuITS region in the different Leptogium clades, Figure S2: The complete phylogenetic tree inferred from the mtSSU and 5.8S regions, Table S1: Specimen information.

Author Contributions: Conceptualization, U.K.; methodology, U.K., A.H. and J.R.; software, U.K.; formal analysis, U.K.; investigation, U.K., V.T. and J.R.; data curation, U.K. and J.R.; writing-original draft preparation, U.K.; writing-review and editing, U.K., J.R., V.T., A.H., P.M.K. and N.P.M.; visualization, U.K. and J.R.; project administration, U.K., A.H. and J.R.; funding acquisition, U.K. and J.R. All authors have read and agreed to the published version of the manuscript. 
Funding: This project has received funding from the German Research Foundation (DFG) with the grant number 408295270 (U.K.), and from the European Union's Horizon 2020 research and innovation programme under the Marie Sklodowska-Curie grant agreement No 705777 (U.K. and J.R.).

Institutional Review Board Statement: Not applicable.

Informed Consent Statement: Not applicable.

Data Availability Statement: The data presented in this study are openly available in NCBI GenBank and the accession numbers are available in Table S1.

Acknowledgments: We thank Petri Pellikka and the staff of the Taita Research Station of University of Helsinki for provision of research facilities and accommodation and the staff of the DFGfunded Kilimanjaro Research Unit. Special thanks are addressed to Claudia Hemp (University of Bayreuth) for her invaluable administrative support with the work in Tanzania. The field work in Kenya was carried out under the National Council for Science and Technology, Kenya, permit No. NCST / RCD/17/012/33 and the work in Tanzania was carried out under the Tanzania Commission for Science and Technology permit no. 2016-368-NA-96-44.

Conflicts of Interest: The authors declare no conflict of interest. The funders had no role in the design of the study; in the collection, analyses, or interpretation of data; in the writing of the manuscript, or in the decision to publish the results.

\section{References}

1. Myers, N.; Mittermeier, R.A.; Mittermeier, C.G.; da Fonseca, G.A.; Kent, J. Biodiversity hotspots for conservation priorities. Nature 2000, 403, 853-858. [CrossRef]

2. Hemp, C.; Kehl, S.; Schultz, O.; Wägele, J.W.; Hemp, A. Climatic fluctuations and orogenesis as motors for speciation in East Africa: Case study on Parepistaurus Karsch, 1896 (Orthoptera). Syst. Entomol. 2015, 40, 17-34. [CrossRef]

3. Merckx, V.S.F.T.; Hendriks, K.P.; Beentjes, K.K.; Mennes, C.B.; Becking, L.E.; Peijnenburg, K.T.C.A.; Afendy, A.; Arumugam, N.; de Boer, H.; Biun, A.; et al. Evolution of endemism on a young tropical mountain. Nature 2015, 524, 347-350. [CrossRef]

4. Schwery, O.; Onstein, R.E.; Bouchenak-Khelladi, Y.; Xing, Y.; Carter, R.J.; Linder, H.P. As old as the mountains: The radiations of the Ericaceae. New Phytol. 2015, 207, 355-367. [CrossRef]

5. Hemp, A.; Hemp, C. Broken bridges: The isolation of Kilimanjaro's ecosystem. Glob. Chang. Biol. 2018, 24, 3499-3507. [CrossRef]

6. Wasser, S.K.; Lovett, J.C. Introduction to the biography and ecology of the rain forests of eastern Africa. In Biogeography and Ecology of the Rain Forests of Eastern Africa; Lovett, J.C., Wasser, S.K., Eds.; Cambridge University Press: Cambridge, UK, 1993; pp. 3-8. ISBN 0-521-43083-6.

7. Hemp, C.; Grzywacz, B.; Warchałowska-Śliwa, E.; Hemp, A. Topography and climatic fluctuations boosting speciation: Biogeography and a molecular phylogeny of the East African genera Afroanthracites Hemp \& Ingrisch and Afroagraecia Ingrisch \& Hemp (Orthoptera, Tettigoniidae, Conocephalinae, Agraeciini). Org. Divers. Evol. 2016, 16, 211-223. [CrossRef]

8. Lovett, J.C.; Wasser, S.K. Biogeography and Ecology of the Rain Forests of Eastern Africa; Lovett, J.C., Wasser, S.K., Eds.; Cambridge University Press: Cambridge, UK, 1993; ISBN 0-521-43083-6.

9. Medley, K.E.; Kalibo, H.W. Ethnobotanical Survey of 'Wild' Woody Plant Resources at Mount Kasigau, Kenya. J. East Afr. Nat. Hist. 2007, 96, 149-186. [CrossRef]

10. Bytebier, B. Taita Hills Biodiversity Project Report; National Museums of Kenya: Nairobi, Kenya, 2001.

11. Harper, E.B.; Measey, G.J.; Patrick, D.A.; Menegon, M.; Vonesh, J.R. Field Guide to the Amphibians of the Eastern Arc Mountains and Coastal Forests of Tanzania and Kenya; Camerapix Publishers International: Nairobi, Kenya, 2010; ISBN 9-781904-722489.

12. Burgess, N.D.; Butynski, T.M.; Cordeiro, N.J.; Doggart, N.H.; Fjeldså, J.; Howell, K.M.; Kilahama, F.B.; Loader, S.P.; Lovett, J.C.; Mbilinyi, B.; et al. The biological importance of the Eastern Arc Mountains of Tanzania and Kenya. Biol. Conserv. 2007, 134, 209-231. [CrossRef]

13. Hemp, A. Vegetation of Kilimanjaro: Hidden endemics and missing bamboo. Afr. J. Ecol. 2006, 44, 305-328. [CrossRef]

14. Lewis, S.L.; Malhi, Y.; Phillips, O.L. Fingerprinting the impacts of global change on tropical forests. Philos. Trans. R. Soc. B. 2004, 359, 437-462. [CrossRef]

15. Fisher, B. African exception to drivers of deforestation. Nat. Geosci. 2010, 3, 375-376. [CrossRef]

16. Eva, H.D.; Brink, A.; Simonetti, D. Monitoring Land Cover Dynamics in Sub-Saharan Africa; Institute of Environment and Sustainability, European Commission: Ispra, Italy, 2006.

17. Pellikka, P.K.; Lötjönen, M.; Siljander, M.; Lens, L. Airborne remote sensing of spatiotemporal change (1955-2004) in indigenous and exotic forest cover in the Taita Hills, Kenya. Int. J. Appl. Earth Obs. Geoinf. 2009, 11, 221-232. [CrossRef]

18. Balmford, A.; Moore, J.L.; Brooks, T.; Burgess, N.; Hansen, L.A.; Williams, P.; Rahbek, C. Conservation conflicts across Africa. Science 2001, 291, 2616-2619. [CrossRef] [PubMed]

19. Brooks, T.M.; Mittermeier, R.A.; Mittermeier, C.G.; da Fonseca, G.A.B.; Rylands, A.B.; Konstant, W.R.; Flick, P.; Pilgrim, J.; Oldfield, S.; Magin, G.; et al. Habitat Loss and Extinction in the Hotspots of Biodiversity. Conserv. Biol. 2002, 16, 909-923. [CrossRef] 
20. Hemp, A. Climate change-driven forest fires marginalize the impact of ice cap wasting on Kilimanjaro. Glob. Chang. Biol. 2005, 11, 1013-1023. [CrossRef]

21. Pimm, S.L.; Raven, P. Biodiversity. Extinction by numbers. Nature 2000, 403, 843-845. [CrossRef]

22. Laurance, W.F.; Useche, D.C.; Rendeiro, J.; Kalka, M.; Bradshaw, C.J.A.; Sloan, S.P.; Laurance, S.G.; Campbell, M.; Abernethy, K.; Alvarez, P.; et al. Averting biodiversity collapse in tropical forest protected areas. Nature 2012, 489, 290-294. [CrossRef]

23. Alvarenga, L.D.P.; Pôrto, K.C.; de Oliveira, J.R.d.P.M. Habitat loss effects on spatial distribution of non-vascular epiphytes in a Brazilian Atlantic forest. Biodivers. Conserv. 2010, 19, 619-635. [CrossRef]

24. Benítez, A.; Prieto, M.; González, Y.; Aragón, G. Effects of tropical montane forest disturbance on epiphytic macrolichens. Sci. Total Environ. 2012, 441, 169-175. [CrossRef]

25. Aerts, R.; Thijs, K.W.; Lehouck, V.; Beentje, H.; Bytebier, B.; Matthysen, E.; Gulinck, H.; Lens, L.; Muys, B. Woody plant communities of isolated Afromontane cloud forests in Taita Hills, Kenya. Plant Ecol. 2011, 212, 639-649. [CrossRef]

26. Lehouck, V.; Spanhove, T.; Colson, L.; Adringa-Davis, A.; Cordeiro, N.J.; Lens, L. Habitat disturbance reduces seed dispersal of a forest interior tree in a fragmented African cloud forest. Oikos 2009, 118, 1023-1034. [CrossRef]

27. Omoro, L.M.; Pellikka, P.K.; Rogers, P.C. Tree species diversity, richness, and similarity between exotic and indigenous forests in the cloud forests of Eastern Arc Mountains, Taita Hills, Kenya. J. For. Res. 2010, 21, 255-264. [CrossRef]

28. Otálora, M.A.G.; Jørgensen, P.M.; Wedin, M. A revised generic classification of the jelly lichens, Collemataceae. Fungal Divers. 2014, 64, 275-293. [CrossRef]

29. Otálora, M.A.G.; Aragón, G.; Martínez, I.; Wedin, M. Cardinal characters on a slippery slope-A re-evaluation of phylogeny, character evolution, and evolutionary rates in the jelly lichens (Collemataceae s. str). Mol. Phylogenet. Evol. 2013, 68, 185-198. [CrossRef] [PubMed]

30. Wedin, M.; Wiklund, E.; Jørgensen, P.M.; Ekman, S. Slippery when wet: Phylogeny and character evolution in the gelatinous cyanobacterial lichens (Peltigerales, Ascomycetes). Mol. Phylogenet. Evol. 2009, 53, 862-871. [CrossRef]

31. Košuthová, A.; Westberg, M.; Tálora, M.A.G.; Wedin, M. Rostania revised: Testing generic delimitations in Collemataceae (Peltigerales, Lecanoromycetes). MycoKeys 2019, 17-33. [CrossRef]

32. Swinscow, T.D.V.; Krog, H. Macrolichens of East Africa; Natural History Museum Publications: London, UK, 1988 ; ISBN 0565010395.

33. Alstrup, V.; Christensen, S.N. New records of lichens with cyanobacteria from Tanzania and Kenya. Cryptogam. Mycol. 2006, 27, 59-68.

34. Frisch, A.; Hertel, H. Flora of macrolichens in the alpine and subalpine zones of Mount Kenya (Kenya). Sauteria 1998, 9, 363-370.

35. Kirika, P.M.; Ndiritu, G.G.; Mugambi, G.K.; Newton, L.E.; Lumbsch, H.T. Diversity and Altitudinal Distribution of Understorey Corticolous lichens in a tropical montane forest in Kenya (East Africa). Cryptogam. Biodivers. Assess. 2018, 2018, 47-70. [CrossRef]

36. Bjelland, T.; Bendiksby, M.; Frisch, A. Geographically disjunct phylogenetic lineages in Leptogium hibernicum reveal Leptogium krogiae sp. nov. from East Africa. Lichenologist 2017, 49, 239-251. [CrossRef]

37. Kitaura, M.J.; Marcelli, M.P. A revision of Leptogium species with spherical-celled hairs (section Mallotium p.p.). Bryologist 2013, 116, 15-27. [CrossRef]

38. Bytebier, B.; Chuah-Petiot, M. A preliminary checklist of the bryoflora of the Taita Hills, Kenya. Trop. Bryol. 2002, 22, 55-66.

39. Beentje, H.J. An ecological and floristical study of the forests of the Taita Hills, Kenya. Utafiti 1988, 1, $23-66$.

40. Wilder, C.; Brooks, T.; Lens, L. Vegetation Structure and Composition of the Taita Hills Forests. J. East Afr. Nat. Hist. 1998, 87, 181-187. [CrossRef]

41. Thijs, K.W. Tree Community Dynamics and Ecosystem Function in a Tropical Landscape under Deforestation Pressure. Ph.D. Thesis, KU Leuven, Leuven, Belgium, 2015.

42. Thijs, K.W.; Roelen, I.; Musila, W.M. Field Guide to the Woody Plants of Taita Hills, Kenya. J. East Afr. Nat. Hist. 2013, 102, 1-272. [CrossRef]

43. Adriaensen, F.; Githiru, M.; Mwang'ombe, J.; Matthysen, E.; Lens, L. Restoration and Increase of Connectivity among Fragmented Forest Patches in the Taita Hills, South-East Kenya; CEPF Project Report; Critical Ecosystem Partnership Fund: Arlington, VA, USA, 2006.

44. Henkin, M.A.; Medley, K.E.; Maingi, J.K. Biophysical analysis of afromontane forest community types at Mount Kasigau, Kenya. Afr. J. Ecol. 2015, 53, 454-464. [CrossRef]

45. Medley, K.E.; Maingi, J.K. Biogeographic Patterns of Forest Diversity at Mount Kasigau, Kenya. J. East Afr. Nat. Hist. 2015, 103, 1-24. [CrossRef]

46. Lambrechts, C.; Woodley, B.; Hemp, A.; Hemp, C.; Nnyiti, P. Aerial Survey of the Threats to Mt. Kilimanjaro Forests; UNDP: Dar es Salaam, Tanzania, 2002.

47. Rutten, G.; Ensslin, A.; Hemp, A.; Fischer, M. Vertical and Horizontal Vegetation Structure across Natural and Modified Habitat Types at Mount Kilimanjaro. PLoS ONE 2015, 10, e0138822. [CrossRef]

48. Appelhans, T.; Mwangomo, E.; Otte, I.; Detsch, F.; Nauss, T.; Hemp, A. Eco-meteorological characteristics of the southern slopes of Kilimanjaro, Tanzania. Int. J. Climatol. 2016, 36, 3245-3258. [CrossRef]

49. Hemp, A. Continuum or zonation? Altitudinal gradients in the forest vegetation of Mt. Kilimanjaro. Plant Ecolog. 2006, 184, 27-42. [CrossRef]

50. Enroth, J.; Nyqvist, P.; Malombe, I.; Pellikka, P.; Rikkinen, J. Additions to the moss flora of the Taita Hills and Mount Kasigau, Kenya. Pol. Bot. J. 2013, 58, 495-510. [CrossRef] 
51. White, T.J.; Bruns, T.; Lee, S.; Taylor, J. Amplification and direct sequencing of fungal ribosomal RNA genes for phylogenetics. In PRC Protcols: A Guide to Methods and Applications; Innis, M.A., Gelfand, D.H., Sninsky, J.J., White, T.J., Eds.; Academic Press: London, UK, 1990; pp. 315-322. ISBN 0-12-372181-4.

52. Fedrowitz, K.; Kaasalainen, U.; Rikkinen, J. Genotype variability of Nostoc symbionts associated with three epiphytic Nephroma species in a boreal forest landscape. Bryologist 2011, 114, 220-230. [CrossRef]

53. Zoller, S.; Scheidegger, C.; Sperisen, C. Pcr Primers for the Amplification of Mitochondrial Small Subunit Ribosomal DNA of Lichen-forming Ascomycetes. Lichenologist 1999, 31, 511-516. [CrossRef]

54. Hall, T.A. BioEdit: A user-friendly biological sequence alignment editor and analysis program for Windows 95/98/NT. Nucleic Acid Symp. Ser. 1999, 41, 95-98.

55. Müller, K.; Müller, J.; Neinhuis, C.; Quandt, D. PhyDE; Phylogenetic Data Editor. 2010. Available online: http:/ /www.phyde.de/ index.html (accessed on 7 December 2020).

56. Katoh, K.; Rozewicki, J.; Yamada, K.D. MAFFT online service: Multiple sequence alignment, interactive sequence choice and visualization. Brief. Bioinform. 2019, 20, 1160-1166. [CrossRef]

57. Posada, D. jModelTest: Phylogenetic model averaging. Mol. Biol. Evol. 2008, 25, 1253-1256. [CrossRef]

58. Ronquist, F.; Huelsenbeck, J.P. MrBayes 3: Bayesian phylogenetic inference under mixed models. Bioinformatics 2003, 19, 1572-1574. [CrossRef]

59. Miller, M.A.; Pfeiffer, W.; Schwartz, T. Creating the CIPRES Science Gateway for Inference of Large Phylogenetic Trees. In Proceedings of the Gateway Computing Environments Workshop (GCE). Gateway Computing Environments Workshop, New Orleans, LA, USA, 14 November 2010.

60. Olsson, S.; Kaasalainen, U.; Rikkinen, J. Reconstruction of structural evolution in the trnL intron P6b loop of symbiotic Nostoc (Cyanobacteria). Curr. Genet. 2012, 58, 49-58. [CrossRef]

61. Rambaut, A.; Drummond, A.J.; Xie, D.; Baele, G.; Suchard, M.A. Posterior Summarization in Bayesian Phylogenetics Using Tracer 1.7. Syst. Biol. 2018, 67, 901-904. [CrossRef]

62. Stöver, B.C.; Müller, K.F. TreeGraph 2: Combining and visualizing evidence from different phylogenetic analyses. BMC Bioinform. 2010, 11, 7. [CrossRef]

63. Bungartz, F.; Hagedorn, G.; Rambold, G. LIAS Glossary-A Wiki-Based Online Dictionary for Ascomycete Terminology Used by LIAS, the Global Information System for Lichenized and Non-Lichenized Ascomycetes. Available online: http:/ / glossary.lias.net/ (accessed on 7 December 2020).

64. Dodge, C.W. The foliose and fruticose lichens of Costa Rica. I. Ann. Mo. Bot. Gard. 1933, 20, 373-467. [CrossRef]

65. Tavares, C.N. Líquenes da Serra do Gerês. Port. Acta Biol. 1950, 3, 1-189.

66. Kitaura, M.J.; Marcelli, M.P. The Leptogium juressianum complex in southeastern Brazil. Mycotaxon 2012, 120, 215-221. [CrossRef]

67. Swartz, O.P. Nova Genera et Species Plantarum Seu Prodromus Descriptioneum Vegetabilium Maximam Parte Incognitorum qua sub Itinere in Indiam Occidentalem Annis 1783-1787 Digessit Olof Swartz, M.D.; Bibliopoliis Acad. M. Swederi: Holmiae, Upsaliæ \& Aboæ, Sweden, 1788.

68. Kitaura, M.J.; Marcelli, M.P.; Jungbluth, P.; Hora, B.R. Five supposedly well-known species of Leptogium section Mallotium. Mycosphere 2013, 4, 520-530. [CrossRef]

69. Dodge, C.W. Some Lichens of Tropical Africa: IV: Dermatocarpaceae to Pertusariaceae. Beih. Nova Hedwig. 1964, 12, 1-282.

70. Taylor, T. New lichens, principally from the Herbarium of Sir William, J. Hooker. Lond. J. Bot. 1847, 6, $148-197$.

71. Montagne, J.F.C. Sylloge Generum Specierumque Cryptogamarum, Quas in Variis Operibus Descriptas Iconibusque Illustratas, Nunc ad Diagnosim Reductas, Nonnullasque Novas Interjectas, Ordine Systematico Disposuit J.F. Cam. Montagne; J.-B. Baillière: Paris, France, 1856.

72. Kitaura, M.J.; Koch, N.M.; Lucheta, F.; Käffer, M.I.; Schmitt, J.L.; Pedroso, J.; Martins, S.A.; Rodrigues, A.S.; Canêz, L.S. A new species and new records of Leptogium (Ach.) Gray (Collemataceae, Peltigerales) from Rio Grande do Sul State with an identification key for the genus. An. Acad. Bras. Cienc. 2019, 91, e20180313. [CrossRef]

73. Nylander, W. Synopsis Methodica Lichenum Omnium Hucusque Cognitorum, Praemissa Introductione Lingua Gallica; Nabu Press: Charleston, SC, USA, 1858.

74. Kitaura, M.J.; Bernardo, C.M.; Koch, N.M.; Rodrigues, A.S.; Torres, J.-M.; Barbosa, T.D.; Da CANÊZ, L.S.; Spielmann, A.A.; Honda, N.K.; Fleig, M.; et al. Leptogium (Collemataceae, Peltigerales) from Mato Grosso do Sul state, Brazil: Nine new records, three new taxa and a key for the species. Phytotaxa 2019, 399, 127. [CrossRef]

75. Barker-Webb, P.; Berthelot, S. Histoire naturelle des Iles Canaries; Béthune: Paris, France, 1840.

76. Bouly de Lesdain, M. Lichens du Mexique, recueillis par les frères G. Arsène et Amable Saint-Pierre. III Supplément. Ann. Crypt. Exot. 1933, 6, 99-130.

77. Vainio, E.A. Additamenta ad lichenographiam Antillarum illustrandum. Ann. Acad. Sci. Fenn. 1915, 6, 1-226.

78. Jørgensen, P.M. Proposals to reject the name Collema proboscidale and to conserve the name Collema phyllocarpum with a conserved type, thereby stabilizing nomenclature of some tropical Leptogium species (Collemataceae, Lecanorales). Taxon 2002, 51, 567-568. [CrossRef]

79. Jørgensen, P.M.; James, P.W. Studies on Some Leptogium Species of Western Europe. Lichenologist 1983, 15, 109-125. [CrossRef]

80. Muggia, L.; Pérez-Ortega, S.; Kopun, T.; Zellnig, G.; Grube, M. Photobiont selectivity leads to ecological tolerance and evolutionary divergence in a polymorphic complex of lichenized fungi. Ann. Bot. 2014, 114, 463-475. [CrossRef] [PubMed] 
81. Lücking, R.; Dal-Forno, M.; Sikaroodi, M.; Gillevet, P.M.; Bungartz, F.; Moncada, B.; Yánez-Ayabaca, A.; Chaves, J.L.; Coca, L.F.; Lawrey, J.D. A single macrolichen constitutes hundreds of unrecognized species. Proc. Natl. Acad. Sci. USA 2014, 111, 11091-11096. [CrossRef]

82. Magain, N.; Sérusiaux, E. Dismantling the treasured flagship lichen Sticta fuliginosa (Peltigerales) into four species in Western Europe. Mycol. Prog. 2015, 14, 125. [CrossRef]

83. Moncada, B.; Lücking, R.; Suárez, A. Molecular phylogeny of the genus Sticta (lichenized Ascomycota: Lobariaceae) in Colombia. Fungal Divers. 2014, 64, 205-231. [CrossRef]

84. Spribille, T. Relative symbiont input and the lichen symbiotic outcome. Curr. Opin. Plant Biol. 2018, 44, 57-63. [CrossRef]

85. Spribille, T.; Tagirdzhanova, G.; Goyette, S.; Tuovinen, V.; Case, R.; Zandberg, W.F. 3D biofilms: In search of the polysaccharides holding together lichen symbioses. FEMS Microbiol. Lett. 2020, 367. [CrossRef]

86. Rikkinen, J. Habitat shifts and morphological variation of Pseudevernia furfuracea along a topographical gradient. Symb. Bot. Ups. 1997, 32, 223-245. 